\title{
Green Mortgages, EU Taxonomy and Environment Risk Weighted Assets: A Key Link for the Transition
}

\author{
Lorenzo Esposito ${ }^{1,2, *}$, Giuseppe Mastromatteo ${ }^{2}$, Andrea Molocchi ${ }^{3}{ }^{\oplus}$, Paola Cristina Brambilla ${ }^{3}$, \\ Maria Leonor Carvalho ${ }^{3}$, , Pierpaolo Girardi ${ }^{3}$, Benedetta Marmiroli ${ }^{3}$ and Giulio Mela ${ }^{3}$ (I) \\ 1 Bank of Italy Milan Branch, 20121 Milan, Italy \\ 2 Economic Policy Department, Università Cattolica del Sacro Cuore, 20123 Milan, Italy; \\ giuseppe.mastromatteo@unicatt.it \\ 3 Ricerca sul Sistema Energetico SpA, 20134 Milan, Italy; andrea.molocchi@rse-web.it (A.M.); \\ Cristina.Brambilla@rse-web.it (P.C.B.); marialeonor.carvalho@rse-web.it (M.L.C.); \\ pierpalo.girardi@rse-web.it (P.G.); benedetta.marmiroli@rse-web.it (B.M.); giulio.mela@rse-web.it (G.M.) \\ * Correspondence: lorenzo.esposito@unicatt.it
}

Citation: Esposito, L.; Mastromatteo, G.; Molocchi, A.; Brambilla, P.C.;

Carvalho, M.L.; Girardi, P.;

Marmiroli, B.; Mela, G. Green

Mortgages, EU Taxonomy and Environment Risk Weighted Assets:

A Key Link for the Transition.

Sustainability 2022, 14, 1633.

https: / / doi.org/10.3390/su14031633

Academic Editors: Baojie He,

Jun Yang, Ayyoob Sharifi and

Chi Feng

Received: 22 December 2021

Accepted: 28 January 2022

Published: 30 January 2022

Publisher's Note: MDPI stays neutral with regard to jurisdictional claims in published maps and institutional affiliations.

Copyright: (C) 2022 by the authors. Licensee MDPI, Basel, Switzerland. This article is an open access article distributed under the terms and conditions of the Creative Commons Attribution (CC BY) license (https:// creativecommons.org/licenses/by/ $4.0 /)$

\begin{abstract}
The need for a quick and radical green transition gives a key role to the financial system as the main source to fund the change. This debate also involves the development of banking regulation tools able to serve the transition. Building on previous works, we propose a method to weight banks assets that combines conventional financial risks and environmental risks to calculate prudential capital requirements, and we apply it to the EU Taxonomy's technical screening criteria to build an environmental risk indicator based on the buildings' energy consumptions. We show how to calculate the tool endogenously for the taxonomy sections related to buildings (new construction, purchase of building, renovation), thus proving its immediate enforceability, using data from the Lombardy's housing stocks. Finally, we conduct a stress test for the Italian banking system showing that our proposal would be an effective incentive for the banks to fund the green transition of the construction sector. Disclaimer: The views expressed are those of the authors and do not involve the responsibility of the Bank of Italy or RSE.
\end{abstract}

Keywords: climate change; prudential regulation; sustainable finance; EU Taxonomy; green mortgage

\section{Introduction: The EU and the Transition}

This paper deals with the sustainable finance in the building-real estate sector, focusing on green mortgages, and deepens how banking regulation can contribute to the green transition by applying prudential rules that combine the rigorous criteria required by the European Union (EU) Taxonomy with environmental risk assessment methods, based on the life cycle analysis approach (LCA).

In recent years, and particularly since the 2015 Paris Agreement, we have seen a significant change in the perception, both at a mass level and in the financial system, of the importance of the issue of climate change and green finance. In December 2019, the EU has made a number of ambitious environmental commitments [1], aiming to become the first climate-neutral continent by 2050.

The experience of the COVID-19 pandemic confirmed the importance of creating a regulatory framework that favours the mobilization of financial resources towards a quick transition. To be effective, this framework should include many issues, such as standardization of information on environmental disclosure, the development of new financial products (green bonds, green loans, etc.) and tools to ensure financial stability.

A significant part of this debate has been devoted to the banking system, given the importance of banks and financial markets to fund the transition. The EU promoted a financial policy to support the environmental transition needed by the Paris Agreement, in particular with the European Commission Action Plan on financing sustainable growth 
(Communication of 8 March 2018 [2]). The plan set the ambitious goal of establishing a unified classification system for sustainable activities ("Taxonomy"), and announced a series of legislative actions to spread the use of the Taxonomy, both in corporate accounting (through new climate-related guidelines under the so called Non-financial Reporting Directive-NFRD, 2014/95/EU [3]) and in the marketing of financial products to customers (so called "disclosure" Regulation, EU 2088/2019 [4]). The goal is now starting to become operational, with the release of the EU Regulation 2020/852 [5] and of the first EC Delegated Act on climate mitigation and adaptation formally adopted on 4 June 2021 [6]. Even if the Taxonomy regulatory framework must be completed with further delegated acts, it is already a key element to increase the use of green financial products that support the decarbonization process, preventing harmful effects on the other environmental and social dimensions of EU policies, avoiding as much as possible greenwashing practices and lowering the cost of uncertainty in the transition.

The last EC strategy ("Strategy for Financing the Transition to a Sustainable Economy", 6 July 2021) has widened the scope of the Taxonomy in climate mitigation and will consider options to extend the EU Taxonomy framework to "economic activities performing at an intermediate level" [7] (p. 7). The new strategy also acknowledges the importance of green financing that can help households and SMEs to improve the energy performance of their buildings. It also aims at fully involving banks in the transition by linking their lending activities to the Taxonomy, particularly in retail lending. A concrete step in this direction has been made by the new NFRD framework provisions, under which credit institutions will have to precisely evaluate the alignment with the EU Taxonomy of a broad range of assets, including loans, debt securities and collaterals.

According to this new EC strategy, the Commission will explore ways to support energy efficient mortgages in the framework of the Mortgage Credit Directive review (2014/17/EU Directive [8]). Moreover, to encourage green retail lending, the Commission will also ask the European Banking Authority (EBA) for an opinion on the definition and possible supporting tools for green retail loans and green mortgages. European prudential regulators have been already involved in green banking issues, given that the new rules ask banks to disclose prudential information on environmental, social and governance risks, including climate transition and physical risk (Capital Requirements Regulation 2, art 449a [9]).

EBA has received three mandates to assess how to integrate ESG factors into credit risk, with the goal of "reorienting capital flows towards sustainable investment in order to achieve sustainable and inclusive growth" [10]. This implies reshaping credit risk metrics, as well as the Basel 2 tools (in particular, the Internal Capital Adequacy Assessment Process-ICAAP, and the Supervisory Review and Evaluation Process-SREP, jointly used to evaluate the banks since the Basel 2 agreement). Even the EBA proposal for a standard of prudential disclosure on ESG risk is based on the EU Taxonomy. However, its conclusions highlight the main drawback of the binary approach of the Taxonomy: it only allows information on environmental opportunities related to the asset (for example, the percentage of Taxonomy compliant activities), but, for now, it does not provide information on the level of environmental risk related to the asset. In fact, the EBA observes "the lack of a common classification system for environmentally harmful activities or for the identification of sectors and geographies exposed to climate change physical risk" [11] (p. 7). The connection between the Taxonomy framework and risk measurement is at the center of the analysis of this paper that explains how to develop prudential tools combining the criteria required by the EU Taxonomy with the exposure to environmental risk in the building sector. Our aim is to show that is not only necessary but also already possible to create a regulatory tool able to steer the banking system towards green assets financing. We show how to extract the data for energy consumption for the buildings using Lombardy house stock and then proposing a test for the whole of the Italian banking system.

The remaining paper is organized as follows: Section 2 reviews the academic literature on the integration of environmental issues in financial risk, showing the more recent 
developments and the debate on the prudential tool connected to RWAs in the building sector; Section 3 describes the energy transition challenges in the housing sector, introduces the concept of green mortgage, analyses the technical screening criteria of the EU Taxonomy for climate mitigation for sustainable activities in the building sector and provides a more technical description of our proposal; Section 4 is dedicated to the calculation of the external cost indicator related to the building energy efficiency classes, the foundation of our tool that is our contribution to the debate on how to create tools to speed up the transition; Section 5 is devoted to the tool calculation in the different cases considered by the Taxonomy for the building sector (purchase of existing buildings, renewal of buildings, construction and purchase of new buildings). The final section sums up the main conclusions.

\section{Literature Review}

Climate change damages are difficult to predict, due to a range of scientific uncertainties and unforeseeable future socio-economic scenarios $[12,13]$. This is particularly true for transition risks that are connected to costs related to legislative changes (prohibitions, environmental taxes, standards, etc.), technological innovation, change of consumers and investors preferences and other phenomena triggered by the need to achieve the targets (for a definition [14]). These risks are fully endogenous to the transition process itself. For instance, climate change awareness and the public opinion on the transition can influence the political decisions on the government about the regulatory framework for the transition. In the same way, the level of a carbon tax can make an investment viable or not, but for authorities, it is not easy to assess the correct level of an environmental taxation (for a discussion of the Italian case [15]).

Academic literature is gradually acknowledging the role of emissions pricing, not only to regularize the expected costs of transition [16], but also to measure the financial impacts of transition risks; for example, Ref. [17] discusses the role of the carbon tax in South Africa, observing a negative relation between the firms' different intensity of carbon emissions and their financial performance, although the transmission channels between the company's environmental performance and transition risk can be much more complex than company emissions only. A too strong "fossil shock" can harm the economy, triggering under-utilization of capital stocks across countries and productive sectors [18]. Besides uncertainty and nonlinearity of climate change, also endogeneity of transition risks make the traditional models ill-suited to treat the transition, so we should conclude that financial community does not possess yet "methodologies that allow the successful analysis of the risks that climate change poses to financial stability" [19].

To create a reasonably effective model to help policymakers in the transition, many different scientific backgrounds will be needed, although we know that "we still lack a comprehensive quantitative vision of transition risks" [20]. Different theoretical traditions have already been used to model climate change, and as [19] observes, climate risks' characteristics (deep uncertainty, nonlinearity, endogeneity, etc.) "pose fundamental challenges to traditional methods for macroeconomic and financial analysis, which are not well-suited to capturing these characteristics". Other theoretical strands in the literature can be more useful.

A first line of research has been based on stock flow consistent approach models. For instance, Ref. [21] develops a model that connect this approach with input-output analysis to appraise the asset quality, finding that a faster transition will strand more assets and that the amount will be significant anyway ("in the region of $\$ 25$ trillion"). Ref. [22] explicitly suggests a post-Keynesian approach to model transition scenarios. In particular, they present models based on the Dynamic Ecosystem-FINance-Economy (DEFINE) framework that combine an environment block with a financial block to allow for a discussion of different policy proposals. In this context, they find that carbon taxes reduce global warming but can increase financial risks due to their adverse effects on the profitability of firms and credit availability (and hence they find that a combined financial requirement approach and, more generally, a green policy mix determines better 
outcomes than single policies). Ref. [23] observes that the traditional risk metrics, such as the Value at Risk, are backward looking and cannot efficiently treat the transition; given the shortcomings of mainstream models on financial contagion, they propose to use the Network Valuation of Financial Assets (NEVA). This model allows the introduction of different shocks, included a transition risk shock, also allowing for the analysis of the subsequent rounds of effects of the shocks until the fourth degree (for instance, fire-sales contagion effects, bail-inable losses of the banks effects, etc.); in this way, it finds that the more stringent and radical are the policies to tackle the climate change, the bigger the losses for the financial system, so a disorderly transition is a threat to the system (see also [24] for an application of the NEVA approach). Ref. [25] employs an agent-based model (a disequilibrium model called Dystopian Schumpeter meeting Keynes model) to analyse connections among climate change with both financial and economic dynamics; they propose a combination of different policies finding that the exact mix is decisive to determine the results (in particular fiscal policy and prudential regulation).

All these works deal with financial regulation given the importance of bank's lending to foster the transition. However, the difficulties we exposed mean that none of them proposes a usable prudential rule to help the transition, limiting the discussion on a macroeconomic level. More traditional models are also used in the same way. For instance, Ref. [26] analyses the transition risk using a Dynamic Stochastic General Equilibrium model (the standard models used by central banks to conduct the monetary policy), finding that macroprudential policies are not enough to allow the transition due to financial frictions (i.e., imperfections in the financial systems that create financial instability). However, once again, no microprudential tools are proposed.

A limit of all these models is their reliance on very specific assumptions that it is difficult to use as the foundation of a regulatory framework (as well as an appraisal of its possible effects on the banking industry); moreover, a huge empirical effort is needed to support them, thus forcing a long delay in their possible adoption. Thirdly, when a model has many assumptions, if empirical results are dissimilar, it is difficult to assess what assumption is "responsible" for the differences. Even in the case of the adoption of Basel 2 and Basel 3, impact studies gave different results (examples, for the EU, in [27]). For instance, a recent Basel Committee paper sums up empirical studies concerning the move from Basel 2 to Basel 3 rules that report changes in GDP ranging, in the case of the Euro area, from $-0.4 \%$ to $+1.2 \%$ [28].

All these aspects suggest that the only possibility to have an effective and rapidly enforceable rule is that it is as simple and assumption-neutral as possible. To push in the direction of a discussion of practical proposals, Ref. [29] proposed to internalize the environmental risk generated by the debtor in the lender's cost of capital, correcting the traditional risk weighting, thus passing from the usual RWAs (risk weighted assets) to the broader concept of ERWAs (environment risk weighted assets). The proposal implies a double weighting of the bank's asset, the ordinary $(r)$ and the environmental one $(c)$. In formulas, the single asset in a bank portfolio becomes

$$
e_{i}=c_{i} r_{i} a_{i}
$$

where $a$ is the book value of the asset, $r$ is the weight assigned to the asset by the existing prudential framework and $c$ is the pollution coefficient assigned to that asset.

Concretely, given the lack of data at the corporate or specific product level, authors suggested the multiplication of the specific RWA by a coefficient that represents the sectoral intensity of health and environmental external costs of air emissions generated by the activities financed by the counterparty for technical details, we refer to [29]. To make it viable in terms of prudential regulation, the value of the environmental coefficient re-proportioning the RWA has been set between 0.5 and 1.5 (where 1 is the average of the sectoral environmental impact, taken as a threshold between non-green and green activities, and where the minimum is assigned only to economic activities producing zero harmful emissions-zero external costs). The work also underlined that, to be effective, 
the instrument should be applied to the single credit line, but, lacking emissions data on the single lines, the use of a sectoral average was suggested, based on the available environmental statistics (so called NAMEA air emissions that links emissions to the EU economic activity accounting system-NACE).

In a second paper [30], the ERWA approach has been expanded by taking into account the EU Taxonomy regulation in its "pre-print" version (political agreement between the European Council and the European Parliament of 18 December 2019) and the proposal of the Technical Expert Group [31] of the European Commission for the technical regulation of the climate mitigation section of the Taxonomy; the paper explains how to integrate these regulations into a single consistent approach that covers almost the entire range of banking assets, making its application as business model-neutral as possible. The proposal for an integrated ERWA-Taxonomy approach has been discussed in various scientific and institutional fora [32], and to our knowledge, it is still the only proposal of a banking regulation tool ready for application at the micro-prudential level. In the following Table 1, we have summed up the comments that scholars have made on ERWAs and possible answers.

Table 1. Comments by scholars on ERWAs and possible answers.

\section{ERWAs must be calibrated carefully due to the complexity of the global value chains of production [33].}

In [30] both a direct and an indirect life-cycle approach using input-output analysis is proposed to this end. More detailed sector-based external cost values for air emissions in Italy using this approach are provided in [34], with insights on how to calculate values for all countries using OECD input-output tables and covering sectoral global supply chains.

This issue is discussed in details in [30]. Sectoral data can be used as default values. More granular data at the company level are going to be collected by banks in the UE under the regulatory process of NFRD described above.

ERWAs can be linked to the new data and Key Performance Indicators required by the Taxonomy and the NFRD regulations, allowing a gradual implementation; at any rate, a gradualist approach is always used in banking regulation.

More empirical analyses are needed to test the ERWAs effect, as it was made to test Basel 2 and Basel 3 requirements. However, ERWAs are a micro-prudential tool and should be appraised as such, while macroeconomic and macro-financial variables should be preferred when assessing macroprudential tools. explored [35].
ERWAs are based on the external costs of air emission (related to the asset/borrower) because they are widely used as indicators related to environmental damages. Scenario analysis can be used to properly estimate the expected external costs of air emissions although in a macroprudential environment.
There is no widely accepted methodology yet to assess climate-related risks and verify whether financial firms take these risks into account in their lending practices. For this purpose, the main tool is a reliable scenario analysis [25].
In this paper, we develop a proposal that takes into account the final version of the Taxonomy regulation [36] and of the technical screening criteria for climate mitigation (Ref. [6] Annex I); this allows the development of prudential rules that are able to rapidly change banks decision making in loans and mortgages related to buildings in line with the EU Taxonomy aims.

\section{The Energy Challenge in the Housing Sector, Green Mortgages and the Taxonomy}

The housing sector is key to the transition. The environmental impacts of buildings include a large range of effects, from the extraction and production of materials and components to the building's use in its lifetime and the disposal of waste produced [37,38]. Current EU policies (the Energy Performance of Buildings Directives) deal in detail with the energy performance of buildings during the use phase because buildings account for $40 \%$ of the EU's final energy consumptions and 36\% of its $\mathrm{CO}_{2}$ emissions [39], thus representing the largest source of energy consumption in Europe. Moreover, according to Eurostat [40], 
the evolution of the final energy consumptions by households in the EU in the last decade is worsening, with a 25\% increase in the 2010-2019 period (see Figure 1: EU28 data are not available).

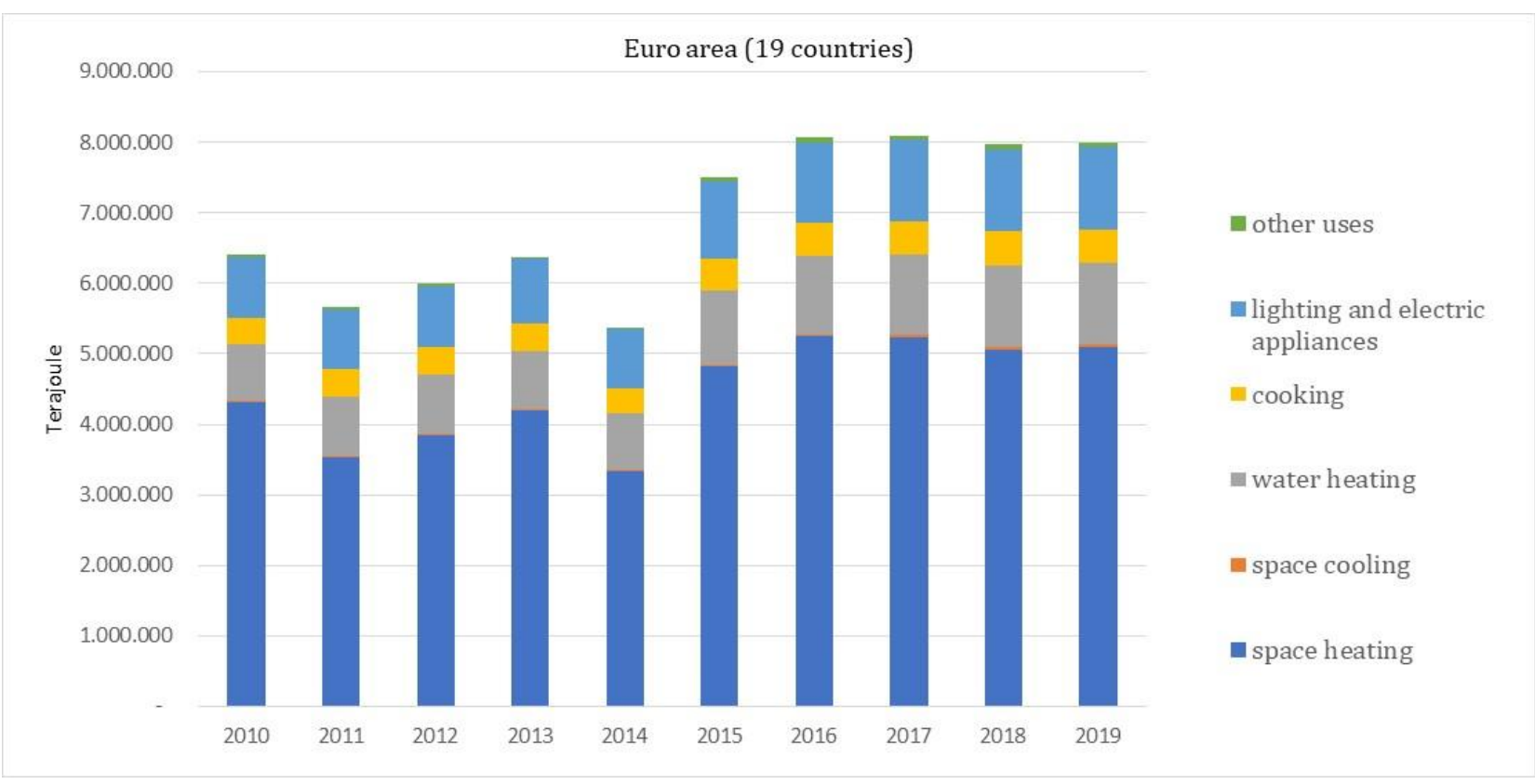

Figure 1. Disaggregated final energy consumption in EU19 households (Terajoule). Source: [40].

The main difficulty of reducing energy consumption in the building sector is the fact that the stock of buildings in the EU is relatively old, with more than $40 \%$ of them built before 1960 and 90\% before 1990, and older buildings typically use much more energy than new buildings. The rate at which new buildings either replace this old stock, or expand the total stock, is very low (about $0.7 \%$ in the EU27, with $0.1 \%$ for Italy in 2019, according to European Mortgage Federation (EMF, Ref. [41]). This implies that, if the energy consumptions and $\mathrm{CO}_{2}$ emissions of buildings are to be reduced, deep energy requalification through renovation of existing buildings is paramount [39]. With the Renovation Wave Strategy [42], developed to enforce the EU Green Deal commitments in the buildings sector, the Commission announced a plan of action to at least double renovation rates in the next ten years and make sure renovations lead to higher energy and resource efficiency. According to a recent study made by JRC-European Commission [43] on the potential of "nearly zero emission" renovations (interventions that combine actions on the envelope, thermal systems and renewable energy production systems of existing buildings), a gradual increase from the current average of $1 \%$ to more than $2 \%$ within the next 10 years and maintained thereafter would result in the renovation of $79 \%$ of existing homes by 2050, allowing a reduction of 1517 TWh $(-38.5 \%)$ in the EU primary consumptions.

\subsection{The Role of Green Mortgages}

Dimensionally, mortgages constitute the main component of the assets of EU banks (around 30\%), a figure that borders on 50\% of the area's GDP. In the year before the pandemic, the mortgage outstanding was around 7 trillion, with 2.7 trillion of connected bonds, showing the importance of the sector for the financial system [41]. The importance of the proposal for a prudential weighting specific for green mortgages stems from the fact that, in Italy but also elsewhere, most houses are bought using mortgages. Data of Ente Nazionale Energie Alternative (ENEA) indicate that in the last three years (2018-2020), the proportion of homes purchased on credit was around 70\% [44]. The situation in the EU varies, but residential mortgages are a vital part of the housing market everywhere. 
The functioning of the prudential regulation RWAs mechanism, in the case of residential mortgages, was revised with the new capital agreement (Basel3), which made the weighting more risk-sensitive [45]. While in Basel 2 the standardized approach assigned the same RWA to all residential mortgages, in the new approach, it depends on the Loan to Value Ratio (LTV) of the mortgage. The same principle applies to exposures to the commercial real estate sector, although we do not include it in the discussion. In the following Table 2, we show the current regulatory connection between LTV and RWA:

Table 2. RWA coefficient for residential mortgages in banking regulation (simplified). Source: [45].

\begin{tabular}{ccccccc}
\hline LTV Bands & Below 50\% & $\mathbf{5 0 - 6 0 \%}$ & $\mathbf{6 0 - 7 0 \%}$ & $\mathbf{8 0 - 9 0 \%}$ & $\mathbf{9 0 - 1 0 0 \%}$ & Above 100\% \\
\hline General Residential Real Estate & $20 \%$ & $25 \%$ & $30 \%$ & $40 \%$ & $50 \%$ & $70 \%$ \\
\hline Income-producing Residential Real Estate & $30 \%$ & $35 \%$ & $45 \%$ & $60 \%$ & $75 \%$ & $105 \%$ \\
\hline
\end{tabular}

The strategic importance of mortgages in contributing to the energy requalification of buildings is behind the Energy Efficient Mortgages Initiative (EEMI) jointly led by the EMF and the European Covered Bond Council. The initiative is based on the idea that green mortgages are less risky for the lender. In this regard, they noted this: "One of the key premises of [our] Initiative is that energy efficiency has a positive impact on credit risk" [46]. For now, the scientific literature on the subject is in its initial state and is focused on the US market; the studies "find evidence of a significant reduction in default risk associated with energy efficiency. This effect is larger for houses that are more energy efficient" [47] and some studies confirm that "buildings' energy efficiency is associated with lower probability of default" [48], see also [49]. Ref. [50] reports 61 different studies that assess the impact of an improvement in energy efficiency for building, finding that "implementing energy efficiency measures in buildings have important benefits for the developer/owner, the tenants, the society and the environment" via cost reduction and reputation. Ref. [51], dealing with the UK market, found that "mortgages against energy-efficient properties are less frequently in payment arrears" even taking into account borrowers' income. Therefore, "the energy efficiency of a property is a relevant predictor of mortgage payment arrears".

In the US case, the influencing factors seem to be double. First, green homes have lower operating costs and therefore suffer less from changes in energy prices; secondly, there is a "green price premium" of houses with a lower environmental impact, as also seems to happen in the case of green bonds. In addition to a lower operating cost, properties with greater energy efficiency are less exposed to transition risk, if, in the future, tax regulations were aimed at discouraging greenhouse gases emissions based on a carbon tax or an excise duty increase on fossil fuel used for the building's energy services. Researches show that green mortgages are attractive to borrowers [52] and that green bonds created to finance them are equally attractive to investors [46]. Furthermore, their prices confirm a "green premium", even in the case of commercial real estate (for the Milan case, see [53]).

More empirical evidence connected to energy efficient mortgage assets is needed, although it is important to define already what an energy efficient mortgage is (for a definition [54]). Even if this task is at an early stage, current data show that financing more efficient houses (i.e., with less external and energy costs) is convenient for the banks. In the last years, EEMI has published several studies that, also commenting other empirical studies, confirm this idea (see, for instance, Ref. [48] where eight papers, published between 2014 and 2020, are summarized). These studies show the strategic importance of the green mortgage market to put together sustainability in terms of environment and of banking business model. For the Italian case, data collected by a set of intermediaries operating on the residential mortgage market show contradictory results: lower than average percentages of defaulted loans for low efficiency classes $\mathrm{E}$ and $\mathrm{F}$ and higher than average percentages for the relatively high efficiency class B (see Table 3). 
Table 3. Data on defaulted mortgages by energy efficiency rating in selected Italian regions.

\begin{tabular}{ccc}
\hline $\begin{array}{c}\text { Rating } \\
\text { Category } \\
\text { (EPC) }\end{array}$ & $\begin{array}{c}\text { All } \\
\text { (\% of the Total Sample of } \\
\text { Mortgages) }\end{array}$ & $\begin{array}{c}\text { Defaulted } \\
\text { (\% within the Category) }\end{array}$ \\
\hline A & 6.93 & 0.79 \\
\hline B & 6.02 & 1.62 \\
\hline C & 7.38 & 1.45 \\
\hline D & 12.28 & 1.13 \\
\hline E & 15.7 & 1.29 \\
\hline F & 18.64 & 1.21 \\
\hline G & 33.04 & 1.87 \\
\hline Total & 100.00 & 1.44 \\
\hline
\end{tabular}

Source: [49].

As we said, data are still initial in terms of geography and sample size, and they are related to a past situation; it is not certain how much they can represent the transmission channels of environmental risk during the transition. Moreover, green loans are needed particularly to finance deep renovations that require longer periods of returns on investment through the expected flow of fossil fuel savings, and this could lead to a higher (rather than lower) risk of default. A recent modeling work [55] that estimated the curve of $\mathrm{CO}_{2}$ abatement costs for Italy, using the most promising measures and technologies to curb $\mathrm{CO}_{2}$ emissions in all end-use energy sectors, highlighted that the most promising energy efficiency measures and/or renewable technologies for residential building (such as interventions on the building envelope, substitution of thermal heating plants, etc.) entail net costs rather than net returns.

Overall, it is difficult to assess the link between financial risk and transition risk through the cost of ownership channel (internal costs). On the contrary, if we analyze transition risk through environmental transmission channels (by calculating the external costs generated by the asset's energy consumption class), we could rely on an indicator that can represent the optimal environmental policies and that is more clearly related to the energy efficiency class of the building. This is the key point: transition risk can be measured through the borrower exposition to optimal environmental taxes needed for the transition. The higher the air emissions related to the building energy consumptions, the higher the borrower exposition to environmental taxes. The higher the tax pressure to achieve the environmental targets at the lower cost, the higher the borrower exposition to transition risk, given the building's energy consumptions and air emissions profile.

\subsection{The Criteria for Green Mortgages in the EU Taxonomy}

The development of the ERWA approach to green loans for the building sector must take into account the new regulatory framework introduced by the Taxonomy [5] and the technical screening for climate mitigation (Annex 1 of [6]). The EU Regulation 2020/852 introduces a common framework of rules to define environmentally sustainable activities, to be used by financial markets participants in the development and marketing of financial products or corporate bonds labeled as environmentally sustainable investments. We refer to the Art. 3 of the Regulation for the criteria that makes an economic activity environmentally sustainable.

The first Commission Delegated Act on the technical screening criteria for climate mitigation and adaptation has been officially approved on the 6 of June 2021 [6], while further Delegated Acts on the other environmental objectives are expected in 2022 and 2023. Annex I of the first Delegated Act establishes the technical screening criteria to determine whether an economic activity contributes substantially to climate change mitigation and causes no significant harm to the Taxonomy other environmental objectives. It is a wide 
document made of 88 activity cards classified into nine groups of activity. One of these groups is "Construction and real estate activities" and is made of seven cards, three of them focused on buildings (see Table 4).

Table 4. Summary of the technical screening criteria for climate mitigation required by the Taxonomy for residential buildings. Source: Annex 1 of [6].

\begin{tabular}{|c|c|c|}
\hline Category of Activity & Description of the Activity & Technical Screening Criteria \\
\hline $\begin{array}{l}7.1 \text { Construction of new } \\
\text { buildings }\end{array}$ & $\begin{array}{l}\text { Development of building projects for } \\
\text { residential and nonresidential buildings } \\
\ldots \text { for later sale as well as the } \\
\text { construction of complete residential or } \\
\text { nonresidential buildings, on own account } \\
\text { for sale or on a fee or contract basis. } \\
\text { (NACE codes F41.1, F41.2, F43) }\end{array}$ & $\begin{array}{l}\text { The Primary Energy Demand (PED), defining the } \\
\text { energy performance of the building resulting from } \\
\text { the construction, is at least } 10 \% \text { lower than the } \\
\text { threshold set for the nearly zero-energy building (NZEB) } \\
\text { requirements in national measures implementing } \\
\text { Directive } 2010 / 31 \text { /EU of the European Parliament } \\
\text { and of the Council. The energy performance is } \\
\text { certified using an as built Energy Performance } \\
\text { Certificate (EPC). }\end{array}$ \\
\hline
\end{tabular}

The building renovation complies with the applicable requirements for major renovations (as set in national and regional regulations).

Alternatively, it leads to a reduction of primary energy

7.2 Renovation of existing buildings
Construction and civil engineering works or preparation thereof.

(NACE codes: F41, F43) demand (PED) of at least 30\%. The 30\% improvement results from an actual reduction in primary energy demand (where the reductions in net primary energy demand through renewable energy sources are not considered) and can be achieved through a succession of measures within a maximum of three years.

1. For buildings built before 31 December 2020, the building has an Energy Performance Certificate (EPC) of at least of class $A$. As an alternative, the building is within the top $15 \%$ of the national or regional building stock expressed as operational PED (with adequate evidence), which at least compares the performance of the relevant asset to the performance of the national or regional stock built within 31 December 2020 and at least distinguishes between residential and nonresidential buildings.

2. For buildings built after 31 December 2020, the building meets the criteria specified in Section 7.1 of this Annex that are relevant at the time of the acquisition.
7.7 Acquisition and ownership of buildings
Buying real estate and exercising (NACE code: L68).

The keystone of the integration of the Taxonomy's technical screening criteria into the ERWA approach for prudential requirements in the building/real estate sector is the energy performance certificate (EPC), introduced in $2002(2002 / 91 / E C)$ and revised in 2010 (2010/31/EU) and 2018 (2018/844/EU). In [30], it was suggested to exogenously link the ERWA values for mortgages to the EPC energy efficiency class, by assigning the ERWA minimum value of 0.5 to the Taxonomy-compliant classes and scaling the other noncompliant classes by 0.1 until reaching 1.1 for class G. In that proposal, ERWA values were still arbitrarily assigned because of the limited information on environmental and health damages included in the EPC's energy efficiency classes (and its main indicatorprimary energy consumptions). In fact, energy consumptions are responsible not only for $\mathrm{CO}_{2}$ emissions, but also for a variety of other emissions; moreover, air emissions can be related not only to the combustion phase of the energy product but also to other activities, from extraction and processing to the energy transmission and distribution network. The Taxonomy regulation itself sets the principle that a life cycle approach should be taken 
into account in the development of the technical screening criteria. In fact, it states this: "When assessing an economic activity against the criteria set out in paragraph 1, both the environmental impact of the activity itself and the environmental impact of the products and services provided by that activity throughout their life cycle shall be taken into account, in particular by considering the production, use and end of life of those products and services." [5] (art. 17.2).

\section{Materials and Methods}

Having described the regulatory framework, now we can discuss how the ERWAs proposal for green mortgages can become operational with the available data.

\subsection{The Data Set}

To calculate the external costs, we considered the energy consumption performance of buildings in Lombardy that is the main region of Italy ( $16.8 \%$ of Italian population; $15.1 \%$ of the residential space in square meters). The choice is mainly due to the availability of a large and high-quality EPC database (CENED), produced by ARIA (the regional company for innovation and procurement) and promoted by the Lombardy Region, which registers the technical data related to all the buildings of the region for which an EPC is released [56].

The data set contains the energy-related technical information on buildings, as reported in more than 1 million EPC released in Lombardy since 2015. It includes all the buildings classified into three classes (single unit, group of units, a whole building). The EPC can be released for different reasons, mainly related to regulatory obligations: in Lombardy "property transfer" accounts for the majority of EPCs (52.2\%), followed by "rent" (24.4\%), "new construction" (4.4\%), "energy requalification" $(4.2 \%)$, "voluntary EPC" $(4.2 \%)$, "major renovation" $(2.5 \%)$, interventions on thermal plants and other subsidized actions $(2.1 \%)$. As far as the energy efficiency classes are concerned, the following Figure 2 summarizes the evolution of energy efficiency classes of EPCs released in Lombardy each year from 2015 to 2020.

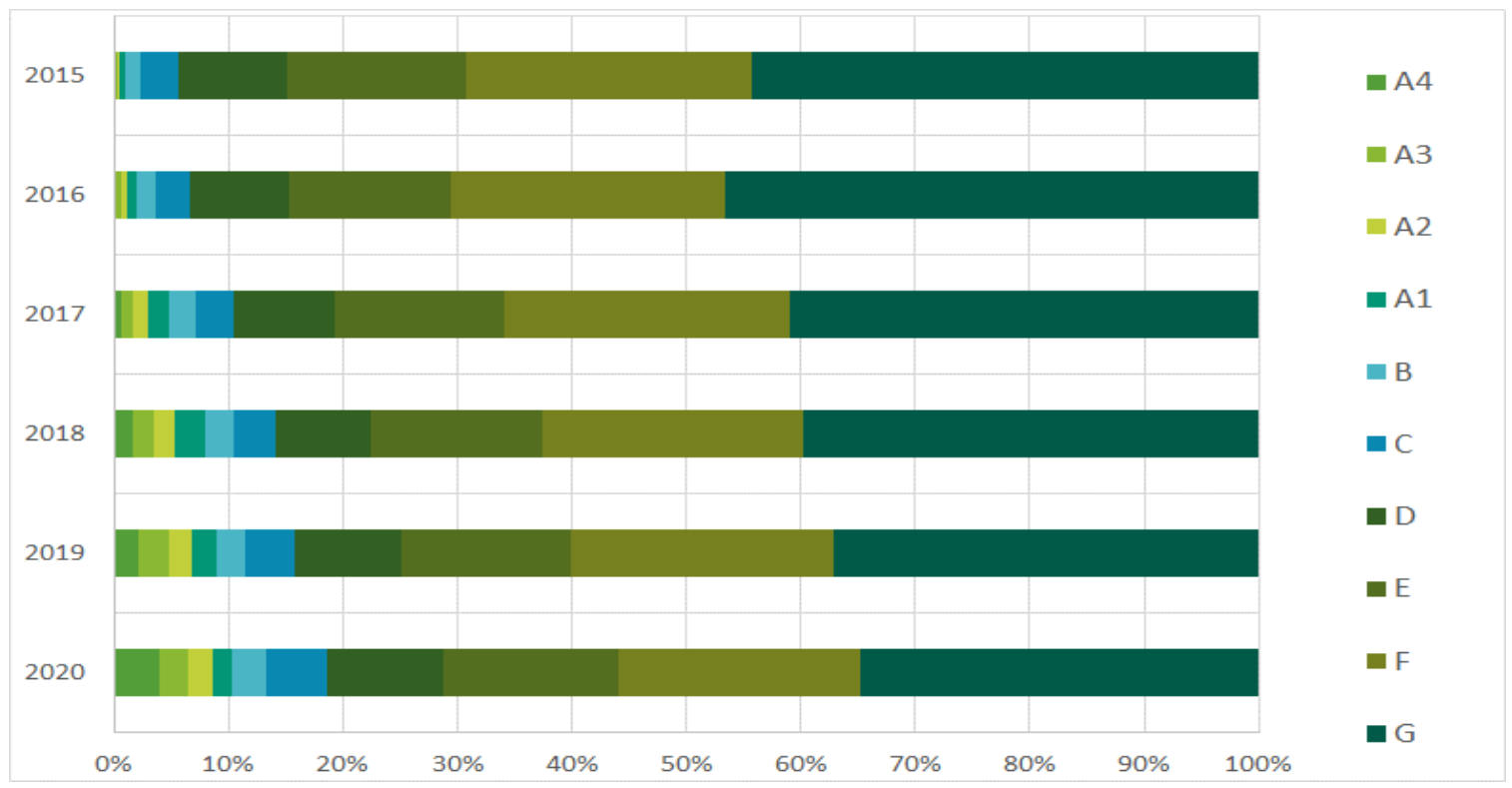

Figure 2. Breakdown of buildings' EPC in Lombardy by energy efficiency class, 2015-2020. Source CENED data (elaborated by C. Belli).

The CENED data base on EPC in Lombardy has been filtered in order to achieve the needed data on the energy performance of existing buildings (in particular, we used the primary energy consumption by $100 \mathrm{~m}^{2}$ that constitutes the starting point of air emissions and external costs estimation) The following criteria have been applied: 
(1) Last EPCs available (EPC collected in January-May 2021);

(2) EPCs related to private properties of buildings with a residential use (public properties and public use of private properties have been excluded);

(3) EPCs belonging to the same climatic zone " $E$ " that is the prevailing in Lombardy (this criterion is due to the fact that the energy consumption index used for EPC classification is related to climatic zones); Italy is classified into six climatic zones related with the winter heating needs (degrees-day) and Lombardy territory has only the two most intense degrees-day zones [57];

(4) exclusion of homes serviced by district heating;

(5) as for winter heating technologies based on combustion technology, the prevailing one (natural gas boilers) has been considered, excluding heating technologies marginally used in Lombardy that in our sample (year 2021 EPCs) account only for $4.5 \%$.

At the end, a sample of 83,343 EPC has been obtained, related to residential properties for a total area of 6.9 million $\mathrm{m}^{2}$. The analysis of the sample, in relation both to the energy efficiency classes and to the occurrences of newly constructed nZEBs, is shown in Table 5. The most populated energy class is $\mathrm{G}$ with 25,486 occurrences $(30.6 \%)$, followed by F with $19,932(23.9 \%)$, while the less populated is A1 (2\%) with 1711 occurrences. The sample can be considered sufficiently large to calculate the average energy consumption (consumption $/ 100 \mathrm{~m}^{2}$ ) in each energy efficiency class in a statistically robust manner. nZEBs in the same sample are $1618(1.9 \%), 55 \%$ falling in the highest efficiency class A4, $30 \%$ in class $\mathrm{A} 3,12 \%$ in $\mathrm{A} 2$ and $3 \%$ in $\mathrm{A} 1$.

Table 5. Distribution of EPC related to private properties for residential use, climatic zone E, Jan.-May 2021, Lombardy.

\begin{tabular}{cccccc}
\hline & \multicolumn{2}{c}{ EPC-Buildings } & \multicolumn{2}{c}{ Total Area of Certified } \\
Buildings & Area/EPC \\
\hline A4 & n. & $\%$ & $\mathbf{m}^{\mathbf{2}}$ & $\%$ & $\mathbf{m}^{\mathbf{2}}$ \\
\hline A3 & 2941 & $3.5 \%$ & 295,0995 & $4.3 \%$ & 100.6 \\
\hline A2 & 2232 & $2.7 \%$ & 211,609 & $3.1 \%$ & 94.8 \\
\hline A1 & 1711 & $2.1 \%$ & 156,489 & $2.3 \%$ & 91.5 \\
\hline B & 1675 & $2.0 \%$ & 147,927 & $2.1 \%$ & 88.3 \\
\hline C & 2424 & $2.9 \%$ & 197,544 & $2.9 \%$ & 81.5 \\
\hline D & 3846 & $4.6 \%$ & 309,285 & $4.5 \%$ & 80.4 \\
\hline E & 8983 & $10.8 \%$ & 722,762 & $10.5 \%$ & 80.5 \\
\hline F & 14,113 & $16.9 \%$ & $1,169,146$ & $16.9 \%$ & 82.8 \\
\hline G & 19,932 & $23.9 \%$ & $1,629,080$ & $23.6 \%$ & 81.7 \\
\hline All classes & 25,486 & $30.6 \%$ & $2,066,688$ & $29.9 \%$ & 81.1 \\
\hline nZEBs & 83,343 & $100.0 \%$ & $6,906,525$ & $100.0 \%$ & 82.9 \\
\hline
\end{tabular}

Source: authors' elaboration of CENED data.

\subsection{The Energy Consumptions of Energy Efficiency Classes}

On the basis of the sample shown in Table 5, the annual consumptions of natural gas and electricity have been calculated in each energy efficiency class and separately for nZEBs. Table 6 shows both the total and average annual gas consumption (averaged for the building's area) obtained in each class and for the subcategory of nZEBs. In the lower energy efficiency classes, natural gas is mainly used by conventional thermal plants used for space heating and domestic hot water, while to obtain higher energy efficiency classes, energy requalification of building must be coupled with renewable-based energy production technologies (solar thermal and PV) and electrified heat pump systems that 
jointly satisfy winter, summer and hot water needs: that is the main reason why average gas consumptions $\left(\mathrm{m}^{3} / 100 \mathrm{~m}^{2}\right)$ tend to become zero approaching the class A4.

Table 6. Natural gas consumptions of the study sample-EPC released in Jan-May 2021. Source: authors' elaboration of CENED data.

\begin{tabular}{cccc}
\hline & Total Natural Gas Consumptions & $\begin{array}{c}\text { Average Gas } \\
\text { Consumptions }\end{array}$ \\
\hline A4 & Million $\mathbf{~}^{\mathbf{3}}$ & $\%$ & $\mathbf{m}^{\mathbf{3}} \mathbf{1 0 0} \mathbf{~ m}^{\mathbf{2}}$ \\
\hline A3 & 0.05 & $0.04 \%$ & 17 \\
\hline A2 & 0.17 & $0.1 \%$ & 80 \\
\hline A1 & 0.35 & $0.3 \%$ & 221 \\
\hline B & 0.57 & $0.4 \%$ & 388 \\
\hline C & 1.32 & $1.0 \%$ & 666 \\
\hline D & 2.66 & $2.1 \%$ & 859 \\
\hline E & 8.24 & $6.4 \%$ & 1140 \\
\hline F & 17.57 & $13.6 \%$ & 1903 \\
\hline G & 32.52 & $25.2 \%$ & 3168 \\
\hline All classes & 65.48 & $50.8 \%$ & 1867 \\
\hline nZEBs & 128.91 & $100.0 \%$ & 45 \\
\hline
\end{tabular}

The opposite trend can be seen for the consumption of grid electricity needed by buildings (see Table 7). In the lower energy efficiency classes, average electricity consumptions (by $100 \mathrm{~m}^{2}$ ) are limited (electricity is mainly used by electric boilers for hot water), while in the middle energy efficiency classes, average electricity consumptions tend to increase notwithstanding the lower energy requirements of building structure, due to an increased adoption in high energy efficiency electric heat pumps jointly used for heating, cooling and hot water. In the high energy efficiency classes (A3 and A4), average grid electricity consumptions tend to decrease due to the higher penetration of own produced electricity with PV systems and hot water obtained with solar thermal panels. nZEBs show an average consumption of electricity that falls between the average consumptions registered for all buildings of A3 and A4 classes.

Table 8 resumes the annual primary energy consumptions of our sample of residential buildings' EPCs in Lombardy region. The indicator excludes energy consumptions related to the use of renewable sources and is expressed in $\mathrm{kWh} / \mathrm{m}^{2}$ (so called EPgl,nren). In the case of nZEBs, the standard equation of the EPC's energy performance (EPgl,nren) is the sum of energy consumption functions related to the following four energy services: winter heating, summer conditioning, domestic hot water and mechanical ventilation [50]. By looking into the CENED database, EPCs of existing buildings that are not in the nZEBs category usually report complete data on winter heating and domestic hot water services, while data on summer conditioning plants are seldom reported, and, at any rate, they are referred to heat pumps (for example $11 \%$ of heat pumps for summer cooling are reported in class $\mathrm{G}$ of our sample). 
Table 7. Electricity consumptions of the study sample-EPC released in Jan-May 2021. Source: authors' elaboration of CENED data.

\begin{tabular}{cccc}
\hline & Total Electricity Consumptions & Average Consumptions \\
\hline AW & GWh & \% & $\mathbf{k W h} / \mathbf{1 0 0} \mathbf{~ m}^{\mathbf{2}}$ \\
\hline A3 & 3.96 & $6.7 \%$ & 1338 \\
\hline A2 & 4.48 & $7.5 \%$ & 2115 \\
\hline A1 & 3.67 & $6.2 \%$ & 2347 \\
\hline B & 3.04 & $5.1 \%$ & 2057 \\
\hline C & 2.29 & $3.8 \%$ & 1158 \\
\hline D & 3.16 & $5.3 \%$ & 1022 \\
\hline E & 6.89 & $11.6 \%$ & 953 \\
\hline F & 8.76 & $14.7 \%$ & 749 \\
\hline G & 10.25 & $17.2 \%$ & 629 \\
\hline All classes & 13.04 & $21.9 \%$ & 862 \\
\hline nZEBs & 59.54 & $100.0 \%$ & 1724 \\
\hline
\end{tabular}

Table 8. Primary energy consumptions (nonrenewable sources) of the study sample-EPC released in January-May 2021, Source: authors' elaboration of CENED data.

\begin{tabular}{cccc}
\hline & Total Primary Energy Consumptions & Average Consumptions (EP $\mathbf{g l}_{\mathbf{g} \text { nen }}$ ) \\
\hline A4 & GWh & $\mathbf{\%}$ & $\mathbf{k W h}_{\mathbf{1 0 0} \mathbf{~ m}^{\mathbf{2}}}$ \\
\hline A3 & 9 & $0.6 \%$ & 3127 \\
\hline A2 & 12 & $0.8 \%$ & 5523 \\
\hline A1 & 12 & $0.8 \%$ & 7581 \\
\hline B & 13 & $0.8 \%$ & 8767 \\
\hline C & 19 & $1.3 \%$ & 9839 \\
\hline D & 36 & $2.3 \%$ & 11,646 \\
\hline E & 105 & $6.8 \%$ & 14,569 \\
\hline F & 212 & $13.7 \%$ & 18,094 \\
\hline G & 378 & $24.5 \%$ & 23,232 \\
\hline All classes & 745 & $48.3 \%$ & 36,061 \\
\hline nZEBs & 1542 & $100.0 \%$ & 22,324 \\
\hline
\end{tabular}

\subsection{Methodology and Results for LCA Air Emissions' External Cost Estimation}

Figure 3 resumes the methodological steps for the estimation of the specific annual external costs (euro $/ 100 \mathrm{~m}^{2}$ ) related to the energy consumption classes of our sample of 83,343 buildings/EPC, within the broader framework of ERWA calculation. The starting point of the analyses (phase 1) are the buildings' average energy consumptions per $100 \mathrm{~m}^{2}$, in terms of electricity and natural gas, as calculated in Section 4.2. The second step of the analysis is the description of the boundaries and assumptions of the external cost evaluation related to buildings. The boundaries of the analysis (phase 2) are the air emissions related to the extraction, production, distribution and combustion processes of the two energy vectors needed to provide the energy services accounted in the EPC of our sample of residential buildings: natural gas and electricity (the energy services covered by the EPC are space heating, domestic hot water, summer cooling and building's ventilation). 


\section{Method}

Phase 1: Buildings' energy consumptions (electricity

and gas), by energy efficiency classes and nZEBs

Phase 2: Boundaries of LCA emissions analysis

(emission species, processes, mix of energy sources,

conversion technologies etc.)

Phase 3: Emissions estimation for natural gas and

electricity, and for the buildings' energy consumption, by

energy efficiency classes and nZEBs

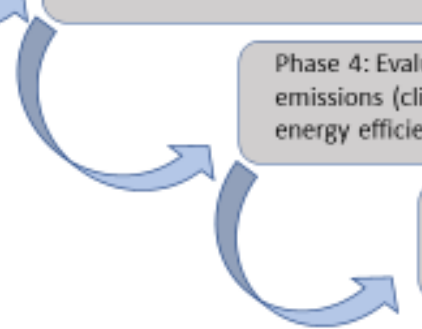

Phase 4: Evaluation of the external costs of LCA issions (climate change and air pollution), by nergy efficiency classes and nZEBs

Phase S: ERWAs for loans related to buildings

$(7.1,7.2,7.7 .1$ and 7.7 .2$)$

Figure 3. Methodology overview. Authors' elaboration.

The three main greenhouse gases $\left(\mathrm{CO}_{2}, \mathrm{~N}_{2} \mathrm{O}, \mathrm{CH}_{4}\right)$ and five of the major air pollutants $\left(\mathrm{PM}_{2.5}, \mathrm{SO}_{2}, \mathrm{NO}_{\mathrm{x}}, \mathrm{NMVOC}, \mathrm{NH}_{3}\right)$ are covered. The three greenhouse gases are quantified in terms of $\mathrm{CO}_{2}$ equivalent emissions using the Global Warming Potential (GWP) values for a 100-year time horizon recommended by the IPCC [58]: $1 \mathrm{t}$ of $\mathrm{N}_{2} \mathrm{O}=265 \mathrm{t} \mathrm{CO}_{2}$, $1 \mathrm{t} \mathrm{CH}_{4}=28 \mathrm{tCO}_{2}$.

For the natural gas combustion process, standard small size $(<50 \mathrm{kWth})$ domestic boilers including condensing boilers are considered for emission factors related to energy consumptions [59] Table 3. Sixteen Tier 2 emission factors in g/GJ for source category 1.A.4.b.i boilers burning natural gas, and a lower calorific value (LCV) of $38.74 \mathrm{MJ} / \mathrm{m}^{3}$ for natural gas consumed in Italy is assumed in the energy to gas conversion. For the upstream and distribution processes, the emission factors are those provided by the LCA database Ecoinvent v. 3.3 [60] for $1 \mathrm{~m}^{3}$ of natural gas delivered at low pressure to the final user in Italy.

In the case of buildings' electricity consumption, the mix of energy sources related to the Internal Gross Consumption (IGC) of the Italian Electricity Balance 2018 [61] is considered for the estimation of life cycle emissions. The mix represents both the energy sources of the Italian production mix and the EU's production mix that is implicit in Italy's electricity net imports. The functional unit for emission estimation is $1 \mathrm{kWh}_{\mathrm{el}}$ delivered to the final user at low voltage, and it includes grid losses due to electricity transformation from high to low voltage (18.0 TWh, that is $5.4 \%$ of IGC [62]). We include all the relevant processes in the analysis of air emissions also including the renewable energy plants considered by GSE statistical reports [63].

Emission estimation (phase 3) is based on many different sources, among which Eurostat energy balances [54], the LCA data base Ecoinvent v. 3.3 [60] and an emission data-set based on the EU Eco-Management and Audit Scheme (EMAS) declarations in the Italian power sector developed at RSE [64]. Because many thermal power plants produce both electricity and heat $(\mathrm{CPH})$, a procedure based on the energy output for allocating emissions separately from electricity and heat is adopted, following Eurostat-OECD/IEA Guidebook [65]. More information on the RSE methodology for the LCA of the Italian electricity mix is available in [66]. 
Table 9 resumes the results of the LCA air emissions estimation for the average gas and electricity consumption (per $100 \mathrm{~m}^{2}$ ) of the energy efficiency classes of our sample of building and of the subset of nZEBs (last row). Table A1 in Appendix A details the LCA emissions $/ 100 \mathrm{~m}^{2}$ separately obtained for natural gas and electricity-related processes.

Table 9. Air emissions related to the energy consumptions of the study sample-EPC released in January-May 2021.

\begin{tabular}{|c|c|c|c|c|c|c|}
\hline & \multicolumn{6}{|c|}{ Natural Gas and Electricity Consumptions-LCA Emissions } \\
\hline & $\mathrm{CO}_{2} \mathrm{eq}$ & $\mathrm{NO}_{\mathbf{x}}$ & $\mathrm{SO}_{2}$ & NMVOC & $\mathbf{P M}_{2.5}$ & NH3 \\
\hline & $\mathrm{kg}-\mathrm{a} / 100 \mathrm{~m}^{2}$ & $\mathrm{~kg}-\mathrm{a} / 100 \mathrm{~m}^{2}$ & $\mathrm{~kg}-\mathrm{a} / 100 \mathrm{~m}^{2}$ & $\mathrm{~kg}-\mathrm{a} / 100 \mathrm{~m}^{2}$ & $\mathrm{~kg}-\mathrm{a} / 100 \mathrm{~m}^{2}$ & $\mathrm{~kg}-\mathrm{a} / 100 \mathrm{~m}^{2}$ \\
\hline A4 & 635.4 & 0.5 & 0.8 & 0.2 & 0.1 & 0.5 \\
\hline A3 & 1159.7 & 0.9 & 1.3 & 0.5 & 0.2 & 0.9 \\
\hline A2 & 1675.6 & 1.3 & 1.8 & 0.7 & 0.3 & 1.0 \\
\hline A1 & 2036.3 & 1.6 & 2.0 & 0.9 & 0.3 & 0.8 \\
\hline B & 2458.4 & 2.0 & 2.1 & 1.2 & 0.3 & 0.5 \\
\hline $\mathrm{C}$ & 2962.4 & 2.4 & 2.5 & 1.5 & 0.4 & 0.4 \\
\hline $\mathrm{D}$ & 3754.7 & 3.0 & 3.1 & 1.9 & 0.5 & 0.4 \\
\hline $\mathrm{E}$ & 4728.5 & 3.8 & 3.8 & 2.5 & 0.6 & 0.3 \\
\hline $\mathrm{F}$ & 6121.2 & 5.0 & 4.8 & 3.2 & 0.8 & 0.3 \\
\hline G & 9553.3 & 7.8 & 7.4 & 5.0 & 1.3 & 0.3 \\
\hline All classes & 5843.2 & 4.7 & 4.6 & 3.1 & 0.8 & 0.4 \\
\hline nZEBs & 885.8 & 0.7 & 1.0 & 0.3 & 0.1 & 0.7 \\
\hline
\end{tabular}

\subsection{A Method of External Cost Evaluation Based on Value Transfer}

For the purpose of external costs evaluation (phase 4), we apply the damage cost values for greenhouse gases and air emissions recommended by the EC's Handbook on external costs of transport [67]. The Handbook sections related to climate change and air emissions are based on European studies that used the environmental impact pathways approach to estimate the external costs associated with air emissions (greenhouse gases, major air pollutants and heavy metals), as in [68-70]. For greenhouse gases $\left(\mathrm{CO}_{2}\right.$ eq.), the central (global) value recommended by the EC Handbook for emissions up to year 2030 is $€_{2016} 100 / \mathrm{t}$ (low $€ 60$-high $€ 189$; see Table 24 in [67]). As to major air pollutants $\left(\mathrm{PM}_{2.5}, \mathrm{SO}_{2}, \mathrm{NO}_{x}, \mathrm{NH}_{3}, \mathrm{NMVOC}\right)$, the reference external costs per unit of mass are the country-differentiated $€_{2016} / \mathrm{kg}$ values in the Table 49 of the Handbook. These values relate to the production processes of all energy sources. To simplify the analysis, we assume that all processes take place in Italy. However, the treatment of well-to-tank external costs in the EC Handbook is not entirely satisfactory. The NEEDS excel tool [71] that has been used by the Handbook to update the external costs values provides differentiated values for "unknown stack height", "low stack" (<100 m) and "high stack" ( $\geq 100 \mathrm{~m})$. The Handbook Table 49 country values are related to the high stack case of emission release for PM only (pages 192-193 of [67]), even if the original scientific source of the Handbook's cost values provides a differentiation for $\mathrm{NO}_{\mathrm{x}}$ and $\mathrm{SO}_{2}$ emissions as well. For example, health damages of $\mathrm{SO}_{2}$ from high stacks should be lower as compared to the EC Handbook's $\mathrm{SO}_{2}$ values provided by Table 49 due to the higher dilution. Therefore, for the purpose of our analysis, we have decided to recalculate the stack height differentiated values by applying to the Handbook's Table 49 single value the NEEDS tool's ratio [71]. In practice, we divide for Italy between "high" and "unknown" external costs values, and subsequently, we use respectively the "high stack" external cost values for assessing the emissions of thermoelectric power plants and the "unknown height" values for assessing emissions related to all other well-to-tank processes (including emissions for residential gas boilers). Moreover, all 
values recommended by the Handbook have been updated to the same reference year (2019) using a value transfer method that requires adjustments of the willingness to pay according to the countries' different income. Value transfer is the procedure of estimating the value of a given good or service of current policy interest (i.e., its health and environmental cost values) in a so-called "policy site" starting from an existing estimate for another site [72]. These methods can be divided, according to [64], in three broad categories; the simplest and most widely used one is the unit value transfer, which is also the one used in this work. Under this approach, the values estimated for the study site in the year of reference are used also in the policy site, upon adjustment for income and price level differences between the two sites. More specifically, we propose the following equation to allow for the value transfer:

$$
V_{p t}=V_{s g}\left(\frac{Y_{p t}}{Y_{s g}}\right)^{\varepsilon}
$$

where $V_{p t}$ is the value in the policy site in year $t, V_{s g}$ is the original estimate in the study site in year $g, Y_{p t}$ is the gross domestic product (GDP) per capita in the policy site in year $t, Y_{s g}$ is the GDP per capita in the study site in year $g$ and $\varepsilon$ is the income elasticity of the willingness to pay for the good we are dealing with. Under this approach, it is assumed that the willingness to pay for the environmental good under analysis is a positive function of income. Such function, however, it is not necessarily linear (as $\varepsilon=1$ would imply) as it depends on individuals' preferences for environmental goods and their health, which, in turn, are strongly related to income levels [73] and to other issues we cannot discuss in this work. In the literature, usually, $\varepsilon$ is assumed to be positive, although usually lower than one $[74,75]$. The Handbook cost values have been updated with different income per capita and $\varepsilon$ values according to the geographical scale of the original cost values: the global scale in the case of $\mathrm{CO}_{2}$ emissions cost and Italy in the case of air pollutants. The update of the global $\mathrm{CO}_{2}$ value requires associating it with each country depending on their income. Starting from the estimates of $\varepsilon$ provided by Navrud [74] for EU countries ( 0.2 for high income countries and 0.5 for Eastern European countries that joined the EU in the 2000s) and World Bank data on GDP per capita at purchasing power parity (PPP), $\varepsilon$ was assumed equal to 0.2 for high income countries, 0.5 for upper-middle-income countries, 0.8 for lower-middle-income countries, 1.2 for low-income countries and 0.5 for the "rest of the world" aggregate. Finally, because the initial values to be transferred were expressed in euro at 2016 prices, the estimated $V_{p t}$ had to be converted to 2019 euro using the Eurozone GDP deflator. In the case of air pollution costs related to Italy, $\varepsilon=0.2$ is assumed. The updated damages values per unit of mass used for the estimation of air emissions external costs are reported in Table A2 in Appendix A.

Table 10 shows the results of the external costs estimate (per $100 \mathrm{~m}^{2}$ ) related to the LCA air emissions due to the annual energy consumptions our sample of buildings. Table A3 in Appendix A details the external costs respectively obtained for natural gas and electricity consumptions and their life-cycle processes.

Buildings in the worst energy efficiency class $(G)$ are responsible for 1310 euro/100 $\mathrm{m}^{2}$ of external cost that is $62 \%$ higher than the sample average. The external cost of the subset of nZEBs is very low (141.4 euro/100 $\mathrm{m}^{2}$ ), falling between the external costs of class A4 and A3 buildings. The share of climate-related external costs amounts to $78 \%$ of the external cost (all classes), but this share is slightly reduced for the most efficient energy classes, going from $79 \%$ (G class) to $67 \%$ in the A4 class. This is due to the increasing electricity share of efficient buildings and to a higher contribution of air pollution-related $\left(\mathrm{NO}_{\mathrm{x}}, \mathrm{SO}_{2}\right.$, NMVOC, $\mathrm{PM}_{2.5}, \mathrm{NH}_{3}$ ) external costs in the case of electricity mix rather than in the case of natural gas (respectively $34 \%$ and $21 \%$ ). 
Table 10. External costs of life-cycle air emissions related to the annual energy consumptions of buildings, by energy efficiency class and nZEBs, Lombardy EPCs January-May 2021, values in $2019 € / 100 \mathrm{~m}^{2}$.

\begin{tabular}{|c|c|c|c|c|c|c|c|}
\hline & \multicolumn{6}{|c|}{ Natural Gas and Electricity Consumptions-External Costs of LCA Emissions } & \multirow{2}{*}{$\begin{array}{c}\begin{array}{c}\text { Total External Costs of } \\
\text { LCA Emissions }\end{array} \\
\text { All Emissions }\end{array}$} \\
\hline & $\mathrm{CO}_{2} \mathrm{eq}$ & $\mathrm{NO}_{\mathbf{x}}$ & $\mathrm{SO}_{2}$ & NMVOC & $\mathbf{P M}_{2.5}$ & $\mathrm{NH}_{3}$ & \\
\hline A4 & 68.5 & 6.7 & 10.1 & 0.3 & 4.8 & 12.2 & 102.7 \\
\hline A3 & 125.1 & 12.5 & 17.5 & 0.5 & 8.5 & 19.4 & 183.4 \\
\hline A2 & 180.7 & 18.4 & 23.3 & 0.8 & 11.8 & 21.5 & 256.6 \\
\hline A1 & 219.6 & 22.9 & 26.1 & 1.1 & 13.8 & 18.9 & 302.3 \\
\hline B & 265.2 & 28.5 & 27.8 & 1.4 & 15.6 & 10.7 & 349.1 \\
\hline$C$ & 319.5 & 34.5 & 32.5 & 1.7 & 18.6 & 9.4 & 416.2 \\
\hline $\mathrm{D}$ & 405.0 & 44.0 & 40.2 & 2.2 & 23.3 & 8.8 & 523.5 \\
\hline $\mathrm{E}$ & 510.0 & 55.6 & 49.4 & 2.8 & 29.0 & 7.0 & 653.9 \\
\hline $\mathrm{F}$ & 660.2 & 72.2 & 63.0 & 3.7 & 37.3 & 6.0 & 842.4 \\
\hline G & 1030.5 & 113.0 & 97.3 & 5.7 & 57.9 & 6.1 & 1310.5 \\
\hline All classes & 630.3 & 68.8 & 60.9 & 3.5 & 35.8 & 8.1 & 807.3 \\
\hline nZEB & 95.5 & 9.4 & 13.6 & 0.4 & 6.6 & 15.8 & 141.4 \\
\hline
\end{tabular}

\section{Discussion: How to Develop the ERWAs in the Building Sector}

In this section, we aim to define endogenously the ERWAs values for the building sector credit lines through an approach that combines the Taxonomy's technical screening criteria with the external cost indicator for buildings. More in detail, we calculate ERWAs values differently for the three Taxonomy sections related to buildings described in Section 3.2.

Prudential regulation can take into account environmental risks using a symmetrical or an asymmetrical tool. Symmetrical tools are those providing both premiums and penalties, while asymmetrical tools are designed to provide only one of these effects. Examples of asymmetrical tools are the green supporting factor and the brown penalty [76]. Although useful, asymmetrical tools do not fit well into how prudential supervision works, because they do not allow a bank to perform an overall measurement of its assets and hence a calculation of its minimum requirements. Moreover, they are not neutral vis à vis the lenders' asset composition. We think that the more secure and rapid way to introduce such a tool is via RWAs because it allows us to put together the risk approach and the policy approach that are at the roots of the debate [35]. We believe that the ERWA mechanism that translates the external costs indicator into an operational measure of the environmental risk generated by the loan is the best available option. Another example of a symmetric tool, similar to the ERWA, is the green weighting factor used by the French banking group Natixis, which gives "a negative (up to $24 \%$ ) or positive (up to $50 \%$ ) adjustment of weighted assets to financial deals according to their environmental color rating" [33].

We explained why we take the EPC as the starting point for the integration of the technical screening criteria required by the Taxonomy sections related to buildings (see the summary provided in Table 4) into the ERWA framework. In particular, three types of EPC-related information are needed: the energy efficiency class, the declaration of compliance with the nZEB requirements, and the indicator of primary energy consumption of nonrenewable sources $\left(\mathrm{EP}_{\mathrm{gl}, \mathrm{nren}}\right)$.

(1) The simplest case is the purchase of an existing building (Taxonomy Section 7.7.1), given that the Taxonomy only requires the EPC's energy efficiency class (at least class A1). Classes from B to $G$ are not compliant (with the Taxonomy); hence we propose to assign the neutral value of ERWA (1.0) to the B class, in order to provide a premium 
to the Taxonomy compliant classes (A4-A1) and a penalty to the less energy efficient classes (C-G). ERWA values for all other energy efficiency classes are calculated using the buildings' life-cycle external costs indicator. As seen for Lombardy, this indicator can be calculated for given administrative areas and climatic zones, starting from the average primary energy consumptions of the EPC we obtain the vector of the external costs related to the average energy consumption of each energy efficiency class, in every area.

(2) In case of renovation of existing building (Taxonomy Section 7.2), ERWAs comes from the Taxonomy requirement of at least a 30\% reduction in terms of primary energy use (excluding nonrenewable energy sources). The matrix of the primary energy savings related to each energy efficiency class change, achieved with the renovation intervention, is the starting point for the calculation of the environmental risk reduction of the asset (the building's external costs savings). The neutral ERWA is assigned to energy saving renovations not achieving the Taxonomy criteria (including those not allowing any energy class change), reserving an ERWA premium to Taxonomy compliant renovations according to the reduction of environmental risk obtained compared with the reduction potential for the same class. On the contrary, a penalty is provided for renovations that increase the building's primary energy use.

(3) In the last two cases (Section 7.1 construction of new buildings and Section 7.7.2 purchase of buildings built after 2020), the technical screening criteria of the Taxonomy are the same: the primary energy demand (excluding renewable sources) is at least $10 \%$ lower than the threshold set for ZEBs in national measures implementing Directive 2010/31/EU. Indeed, a single threshold for nZEBs is not guaranteed in each climatic zone of the EU: in their national transposition of the EPBD, Member States introduced many different requirements for nZEBs, related to the building structure to the energy efficiency of the plants supplying the residential building's energy services and to the percentage of energy consumptions covered with renewable sources [50]. Lacking an EU-wide homogenous approach for nZEBs, these requirements can be translated "ex post" into a single value of the primary energy demand indicator by using statistical analysis of the primary energy consumption values certified by the EPC in a specific area and climatic zone (for example, Lombardy region and climatic zone E in our sample). In this case we suggest assigning (i) the neutral ERWA (1) to the buildings compliant with the country-based rules on nZEBs and (ii) ERWA values $<1$ to buildings compliant with the Taxonomy criteria (at least a 10\% reduction of the nZEB-equivalent primary energy demand), with ERWA values proportional to the external costs of the new building.

In the following paragraphs, we describe ERWAs values calculation in the three cases also providing some examples.

\subsection{ERWAs Values for Credits Related to the Purchase of Existing Buildings (Taxonomy Section 7.7.1)}

The ERWA value for mortgages is based on the following criteria:

(1) The neutral value of ERWA (1.0) is assigned to the B class, to provide a premium to all the Taxonomy compliant classes (A4-A1);

(2) The minimum ERWA value (0.5) is given to mortgages for purchasing existing buildings with the lowest external costs (A4 buildings);

(3) The maximum ERWA value (1.5) is assigned to the energy class with the highest external costs $(G)$.

Table 11 reports the ERWAs values obtained for each energy efficiency class within the ERWA pre-defined boundaries (0.5-1.5), on the basis of the external cost indicator; these values reflect the average external costs calculated for each energy efficiency class. According to the Taxonomy technical screening criteria, only A4-A1 classes can be considered environmentally sustainable. ERWAs values for the compliant classes, calculated with the external cost approach, range from 0.50 (A4) to 0.91 (A1). ERWAs values will provide 
a growing penalty to the other noncompliant classes (C-G). A mortgage for the simple purchase of a house in class $G$ would be highly penalized. These values should help to accelerate the buildings' renovation rate. Borrowers interested in purchasing buildings with an EPC in the C to G range would be pushed by the ERWAs tool to combine the purchase with the needed energy requalification of the building (see Section 5.4).

Table 11. ERWA calculation for Taxonomy Section 7.7.1 (purchase of existing buildings—built before $1 / 1 / 2021)$.

\begin{tabular}{ccc}
\hline EPC & $\begin{array}{c}\text { External Costs Related to the Life-Cycle Emissions of the } \\
\text { Buildings' Energy Consumptions } \\
\text { euro/100 } \mathbf{~ m}^{\mathbf{2}}\end{array}$ & ERWA \\
\hline A4 & 102.65 & 0.50 \\
\hline A3 & 183.43 & 0.66 \\
\hline A2 & 256.57 & 0.81 \\
\hline A1 & 302.31 & 0.91 \\
\hline B & 349.13 & 1.00 \\
\hline C & 416.24 & 1.03 \\
\hline D & 523.49 & 1.09 \\
\hline E & 653.87 & 1.16 \\
\hline F & 842.38 & 1.26 \\
\hline G & 1310.51 & 1.50 \\
\hline
\end{tabular}

5.2. ERWAs Values for Credits Related to the Renovation of Existing Building (Taxonomy Section 7.2)

In this case, the calculation of ERWAs starts from the matrix of the average primary energy savings related to each class change obtained with the renovation intervention (Table 12). Green cells show the class changes compliant with the Taxonomy technical screening of at least a 30\% reduction of primary energy savings, while the grey cells show both the renovations that allow a reduction of primary energy savings of less than $30 \%$ and the renovations that do not allow any energy class change. In most cases, the Taxonomy requires two class jumps. For two cases only, the Taxonomy criteria is reached through a jump of one class (from $\mathrm{G}$ to $\mathrm{F}$ allows $36 \%$ energy saving, and from A3 to A4 allows 43\%). There are also two cases where three class jumps are needed for the Taxonomy criteria: $\mathrm{C}$ to A2 $(-35 \%)$ and B to A3 $(-44 \%)$. In our exercise, class jumps of more than two classes are always Taxonomy compliant. The matrix of the reduction in external cost related to each class jump is then calculated on the basis of the average external cost for each energy efficiency class calculated in Section 4 (see Table 13). As a third step, ERWAs values are calculated by applying the following criteria (see Table 14):

- The neutral ERWA value of 1.0 is assigned to renovations that allow a reduction of primary energy savings of less than $30 \%$ (the Taxonomy criteria is not achieved notwithstanding the energy savings achieved) and to renovations that do not allow any energy class change (grey area);

- The minimum ERWA value is assigned to Taxonomy compliant renovations that allow us to achieve the maximum potential reduction of external cost starting from each class (the maximum potential is always achieved by reaching A4 class);

- ERWAs values for all other class changes are calculated proportionally to the actual benefit (external cost reduction) coming from the building's renewal compared to the maximum potential benefit for the starting class-for instance, ERWA value for a renewal from class $\mathrm{G}$ to $\mathrm{C}$ is obtained through the formula $1-0.5 *$ (BG-C/BG-A4) $=1-0.5 *(894 / 1208)=0.63$, where 894 euro $/ 100 \mathrm{~m}^{2}$ is the external cost reduction obtained with a renewal from class $\mathrm{G}$ to $\mathrm{C}$ and 1208 euro $/ 100 \mathrm{~m}^{2}$ is the maximum 
achievable external cost reduction for renovations starting from class $G$ (i.e., the benefit from class $\mathrm{G}$ to A4).

- As we cannot exclude that some building renovations (not aimed to the building's energy requalification) may lead to a worsening of the energy class of the building, ERWAs are provided until the maximum value of 1.5. Symmetrically, the criteria are proportional to the additional external costs of the renewal compared to the maximum potential increase in the external costs for the starting energy class.

Table 12. Percentage of energy saving for each energy efficiency class change with the renovation intervention.

\begin{tabular}{|c|c|c|c|c|c|c|c|c|c|c|}
\hline From Row to Column & A4 & A3 & A2 & A1 & B & $\mathrm{C}$ & D & E & $\mathbf{F}$ & G \\
\hline A4 & $0 \%$ & $-77 \%$ & $-142 \%$ & $-180 \%$ & $-215 \%$ & $-272 \%$ & $-366 \%$ & $-479 \%$ & $-643 \%$ & $-1053 \%$ \\
\hline A3 & $43 \%$ & $0 \%$ & $-37 \%$ & $-59 \%$ & $-78 \%$ & $-111 \%$ & $-164 \%$ & $-228 \%$ & $-321 \%$ & $-553 \%$ \\
\hline A2 & $59 \%$ & $27 \%$ & $0 \%$ & $-16 \%$ & $-30 \%$ & $-54 \%$ & $-92 \%$ & $-139 \%$ & $-206 \%$ & $-376 \%$ \\
\hline A1 & $64 \%$ & $37 \%$ & $14 \%$ & $0 \%$ & $-12 \%$ & $-33 \%$ & $-66 \%$ & $-106 \%$ & $-165 \%$ & $-311 \%$ \\
\hline B & $68 \%$ & $44 \%$ & $23 \%$ & $11 \%$ & $0 \%$ & $-18 \%$ & $-48 \%$ & $-84 \%$ & $-136 \%$ & $-267 \%$ \\
\hline $\mathrm{C}$ & $73 \%$ & $53 \%$ & $35 \%$ & $25 \%$ & $16 \%$ & $0 \%$ & $-25 \%$ & $-55 \%$ & $-99 \%$ & $-210 \%$ \\
\hline $\mathrm{D}$ & $79 \%$ & $62 \%$ & $48 \%$ & $40 \%$ & $32 \%$ & $20 \%$ & $0 \%$ & $-24 \%$ & $-59 \%$ & $-148 \%$ \\
\hline $\mathrm{E}$ & $83 \%$ & $69 \%$ & $58 \%$ & $52 \%$ & $46 \%$ & $36 \%$ & $19 \%$ & $0 \%$ & $-28 \%$ & $-99 \%$ \\
\hline $\mathrm{F}$ & $87 \%$ & $76 \%$ & $67 \%$ & $62 \%$ & $58 \%$ & $50 \%$ & $37 \%$ & $22 \%$ & $0 \%$ & $-55 \%$ \\
\hline G & $91 \%$ & $85 \%$ & $79 \%$ & $76 \%$ & $73 \%$ & $68 \%$ & $60 \%$ & $50 \%$ & $36 \%$ & $0 \%$ \\
\hline
\end{tabular}

Table 13. Environmental benefit (avoided external cost) of the class change with the renovation intervention, euro $/ 100 \mathrm{~m}^{2}$.

\begin{tabular}{ccccccccccc}
\hline From Row to Column & A4 & A3 & A2 & A1 & B & C & D & E & F & G \\
\hline A4 & 0 & -81 & -154 & -200 & -246 & -314 & -421 & -551 & -740 & -1208 \\
A3 & 81 & 0 & -73 & -119 & -166 & -233 & -340 & -470 & -659 & -1127 \\
\hline A2 & 154 & 73 & 0 & -46 & -93 & -160 & -267 & -397 & -586 & -1054 \\
\hline A1 & 200 & 119 & 46 & 0 & -47 & -114 & -221 & -352 & -540 & -1008 \\
\hline B & 246 & 166 & 93 & 47 & 0 & -67 & -174 & -305 & -493 & -961 \\
\hline C & 314 & 233 & 160 & 114 & 67 & 0 & -107 & -238 & -426 & -894 \\
\hline D & 421 & 340 & 267 & 221 & 174 & 107 & 0 & -130 & -319 & -787 \\
\hline E & 551 & 470 & 397 & 352 & 305 & 238 & 130 & 0 & -189 & -657 \\
\hline F & 740 & 659 & 586 & 540 & 493 & 426 & 319 & 189 & 0 & -468 \\
\hline G & 1208 & 1127 & 1054 & 1008 & 961 & 894 & 787 & 657 & 468 & 0 \\
\hline
\end{tabular}

Table 14. ERWA values for each energy efficiency class change with the building renovation.

\begin{tabular}{ccccccccccc}
\hline From Row to Column & A4 & A3 & A2 & A1 & B & C & D & E & F & G \\
\hline A4 & 1.00 & 1.03 & 1.06 & 1.08 & 1.10 & 1.13 & 1.17 & 1.23 & 1.31 & 1.50 \\
\hline A & 0.50 & 1.00 & 1.03 & 1.05 & 1.07 & 1.10 & 1.15 & 1.21 & 1.29 & 1.50 \\
\hline A2 & 0.50 & 1.00 & 1.00 & 1.02 & 1.04 & 1.08 & 1.13 & 1.19 & 1.28 & 1.50 \\
\hline A1 & 0.50 & 0.70 & 1.00 & 1.00 & 1.02 & 1.06 & 1.11 & 1.17 & 1.27 & 1.50 \\
\hline B & 0.50 & 0.66 & 1.00 & 1.00 & 1.00 & 1.03 & 1.09 & 1.16 & 1.26 & 1.50 \\
\hline C & 0.50 & 0.63 & 0.75 & 1.00 & 1.00 & 1.00 & 1.06 & 1.13 & 1.24 & 1.50 \\
\hline D & 0.50 & 0.60 & 0.68 & 0.74 & 0.79 & 1.00 & 1.00 & 1.08 & 1.20 & 1.50 \\
\hline E & 0.50 & 0.57 & 0.64 & 0.68 & 0.72 & 0.78 & 1.00 & 1.00 & 1.14 & 1.50 \\
\hline F & 0.50 & 0.55 & 0.60 & 0.63 & 0.67 & 0.71 & 0.78 & 1.00 & 1.00 & 1.50 \\
\hline G & 0.50 & 0.53 & 0.56 & 0.58 & 0.60 & 0.63 & 0.67 & 0.73 & 0.81 & 1.00 \\
\hline
\end{tabular}

The suggested approach for ERWAs calculation allows a level playing field for all building renewals whatever is the starting class, with a higher premium that is proportional to the environmental risk reduction achieved by the renewal as compared to the maximum potential for the same starting class. For example, a Taxonomy compliant renovation 
from class $\mathrm{F}$ to $\mathrm{D}$ (37\% of energy saving) achieves a benefit of 319 euro on a maximum of 740 euro/100 $\mathrm{m}^{2}$, obtaining an ERWA of 0.78 , while a deep renovation from the same class to A4 obtains an ERWA of 0.5 because this is the maximum achievable energy efficiency class.

\subsection{ERWAs Values for Lending to the Construction/Purchase of New Buildings (Taxonomy Sections 7.1 and 7.7.2)}

Since 2021, EPBD has required that all new buildings in the EU must comply with nZEB requirements, so we take 1 as the maximum ERWA value for new buildings. We suggest to assign the neutral value also to all new buildings, compliant with the legal requirement, that do not reach the technical screening criteria of the Taxonomy (less than $10 \%$ primary energy reduction as compared to the nZEBs' requirements). ERWA values $<1$ are reserved only to new buildings that are compliant with the Taxonomy, proportionally to their environmental risk. In Table 15, some examples of ERWA calculation are provided, related to our Lombardy sample, made of 1618 nZEBs (from January to May 2021, climatic zone E). In the sample, the average primary energy consumption for $n Z E B s$, as certified by their EPC, is $4280 \mathrm{kWh} / 100 \mathrm{~m}^{2}$, which yields an average external cost of 141.4 euro $/ 100 \mathrm{~m}^{2}$; this energy consumption value, and the corresponding external cost value, are taken as the reference climatic zone threshold to calculate the Taxonomy criteria for nZEBs (at least a $10 \%$ energy consumption reduction from the threshold). If a certified nZEB has a primary energy consumption indicator that does not comply with the Taxonomy criteria, the neutral ERWA value is assigned. A $10 \%$ reduction in primary energy consumption as compared to the reference threshold (example 2) allows a similar reduction of the external costs and an ERWA coefficient of 0.95 . If a higher energy consumption reduction is achieved (29\% in example 3, one that matches the average energy consumptions of nZEB belonging to the A4 class), the proposed ERWA value is 0.85 . If a certified nZEB achieves a $75 \%$ energy consumption reduction as compared to the climatic zone threshold for nZEB (example 4), the external cost reduces from 141.4 euro $/ 100 \mathrm{~m}^{2}$ to 35.4 euro/100 $\mathrm{m}^{2}$, and the proposed ERWA value is 0.63 . In our framework of analysis, buildings with zero primary energy consumptions of fossil fuels produce zero external cost; hence, the ERWA minimum value of 0.5 is assigned.

Table 15. ERWA calculation for Taxonomy Section 7.7.2 (purchase of buildings built after 2020—nZEB compliant). Authors' calculation.

\begin{tabular}{|c|c|c|c|c|}
\hline Categories & Examples & $\begin{array}{c}\text { Primary Energy Consumptions } \\
\text { of Nonrenewable Sources } \\
\left(\mathrm{EP}_{\mathrm{GL}, \mathrm{NREN}}\right)\end{array}$ & $\begin{array}{l}\text { Air Emissions' External } \\
\text { Costs of nZEBs }\end{array}$ & ERWA \\
\hline & Examples & $\mathrm{kWh} / 100 \mathrm{~m}^{2}$ & euro/100 $\mathrm{m}^{2}$ & \\
\hline \multirow{2}{*}{$\begin{array}{c}\text { nZEB compliant with EU } \\
\text { regulations, but not compliant with } \\
\text { the Taxonomy technical screening } \\
\text { criteria } 7.7 .2\end{array}$} & $\begin{array}{l}\text { equivalent threshold for climatic } \\
\text { zone } E \text { (average of primary } \\
\text { energy consumptions of nZEBs) }\end{array}$ & 4280 & 141.4 & 1.00 \\
\hline & $\begin{array}{l}\text { example 1: } 7 \% \text { reduction of the } \\
\text { nZEBs' threshold }\end{array}$ & 3980 & 131.5 & 1.00 \\
\hline \multirow{3}{*}{$\begin{array}{l}\text { nZEB compliant with the Taxonomy } \\
\text { technical screening criteria (at least a } \\
10 \% \text { reduction of the nZEBs' } \\
\text { threshold) }\end{array}$} & $\begin{array}{l}\text { example } 2: 10 \% \text { reduction of the } \\
\text { nZEBs' threshold }\end{array}$ & 3852 & 127.3 & 0.95 \\
\hline & $\begin{array}{l}\text { example } 3: 29 \% \text { reduction of the } \\
\text { nZEBs' threshold (average of } \\
\text { nZEB A1 consumptions) }\end{array}$ & 3031 & 100.2 & 0.85 \\
\hline & $\begin{array}{l}\text { example } 4: 75 \% \text { reduction of the } \\
\text { nZEBs' threshold }\end{array}$ & 1070 & 35.4 & 0.63 \\
\hline $\begin{array}{c}\text { Zero Emissions Building (ERWA } \\
\text { minimum) }\end{array}$ & $\begin{array}{l}\text { zero emissions / zero external } \\
\text { costs }\end{array}$ & 0 & 0 & 0.50 \\
\hline
\end{tabular}

\subsection{ERWAs Values for Credits Aimed at a Renovation Intervention of a Purchased House}

The fourth and last case is the mortgage to buy a house with a subsequent renovation. The purchasing of a house is a great opportunity to promote a deep energy renovation intervention on the building. Our proposal is the following: if the borrower does not adopt 
a renovation project for the building, the ERWA for the simple purchase of an existing building is applied (see Section 5.1). If the borrower receives a mortgage that covers part of the costs of purchase as well as the cost of the renovation project, the bank applies the post-restructuring EPC class connected ERWA, after checking the compliance with the Taxonomy criteria (in our sample related to Lombardy buildings this result corresponds to green cells in Table 14). Here we propose the same ERWA suggested in Section 5.2, with the only difference of an additional criteria to prevent fake energy renewals aimed at ERWA reduction; building renovation projects that maintain the same energy class (no meaningful improvement) will be assigned an ERWA value corresponding to that foreseen for house purchases without restructuring (grey diagonal cells of Table 14). Borrowers of existing buildings of the B-G classes proposing a renovation not achieving the taxonomy $30 \%$ energy saving criteria, but achieving at least a one class jump, can be assigned the neutral ERWA value of 1.0 (yellow cells in Table 14); borrowers of existing buildings of the A1-A3 classes proposing a renovation not achieving the Taxonomy criteria, but achieving at least a one class jump, can be assigned the more favorable purchase ERWA value (near-diagonal grey cells in Table 16).

Table 16. Applicable ERWA values for the purchase of existing building, without renovation (first column) or with renovation (other columns).

\begin{tabular}{|c|c|c|c|c|c|c|c|c|c|c|c|}
\hline & & \multicolumn{10}{|c|}{ Renewal from Row Class to Column Class } \\
\hline & Purchase of Existing Building & G & $\mathbf{F}$ & E & D & C & B & A1 & A2 & A3 & A4 \\
\hline $\mathrm{G}$ & 1.50 & 1.50 & 0.81 & 0.73 & 0.67 & 0.63 & 0.60 & 0.58 & 0.56 & 0.53 & 0.50 \\
\hline $\mathrm{F}$ & 1.26 & & 1.26 & 1.00 & 0.78 & 0.71 & 0.67 & 0.63 & 0.60 & 0.55 & 0.50 \\
\hline E & 1.16 & & & 1.16 & 1.00 & 0.78 & 0.72 & 0.68 & 0.64 & 0.57 & 0.50 \\
\hline $\mathrm{D}$ & 1.09 & & & & 1.09 & 1.00 & 0.79 & 0.74 & 0.68 & 0.60 & 0.50 \\
\hline $\mathrm{C}$ & 1.03 & & & & & 1.03 & 1.00 & 1.00 & 0.75 & 0.63 & 0.50 \\
\hline B & 1.00 & & & & & & 1.00 & 1.00 & 1.00 & 0.66 & 0.50 \\
\hline A1 & 0.91 & & & & & & & 0.91 & 0.91 & 0.70 & 0.50 \\
\hline A2 & 0.81 & & & & & & & & 0.81 & 0.81 & 0.50 \\
\hline A3 & 0.66 & & & & & & & & & 0.66 & 0.50 \\
\hline A4 & 0.50 & & & & & & & & & & 0.50 \\
\hline
\end{tabular}

Legend: Grey: ERWAs for the purchase of existing buildings (Section 5.1); Green: ERWAs for Taxonomy compliant renovations of Section 5.2 (at least a 30\% primary energy saving); Yellow: admitted neutral ERWA (1.00) for Taxonomy noncompliant renovations achieving at least a 1 class jump. Authors' calculation based on CENED data.

To explain how our tool works, we make two examples. In the first, we assume the purchase of a house in class $G$ that costs $€ 100,000$ and with a loan of $€ 80,000$. The Basel 3 risk weight (RWA) for an $80 \%$ LTV is $30 \%$; therefore, the ERWA calculation would be $€ 80,000 * 30 \% * 150 \%=€ 36,000$. If the borrower decides to renovate the house and the firm in charge of the renovation declares that the works aim to achieve class $\mathrm{E}$ (confirmed by a new EPC), the weight of the building's environmental risk will be $73 \%$. If the bank also funds the renovation works for $€ 10,000$, the total loan would be $€ 90,000$; Basel 3 risk weight (RWA) for a $90 \%$ LTV is $40 \%$; therefore, the ERWA calculated on the loan would become $€ 90,000 * 40 \% * 73 \%=€ 26,280$. Even with a higher loan, the bank would have a lower capital requirement (around 30\% less), with a strong push to fund house restructuring. This without taking into account that the energy requalified house would increase its market price, thus giving the bank a more valuable collateral.

In the second example, we use the same data, but the house is in class B and the renovation is aimed at bringing it to A3 class. Here the ERWA calculation without renovation is $€ 80,000 * 30 \% * 100 \%=€ 24,000$; the calculation with the renovation works is $€ 90,000 * 40 \% * 66 \%=€ 23,760$. In this second example, given that the house is already in a good class, the bank would have fewer incentives to include renovation in the loan, although it is still worth it: even if the capital requirement remains of the same order of magnitude, the capital requirement to loan ratio would be reduced from 0.300 to 0.264 . It would still be convenient, for the bank, to fund the building renovation.

In Appendix B, we provide a simulation, using mortgage data of the Italian banking system, to explain how the ERWA mechanism could work vis à vis the ordinary RWAs 
for financing house purchases coupled with energy renovations. By assessing the mortgage value increases and the capital reserves needed with the ERWA mechanism under alternative scenarios, representing different percentages of renovations, we show that the proposed ERWA tool would provide a strong but realistic incentive to the banks for funding green mortgages covering also building renovation projects.

To sum up our proposal: the ERWA tool is able to intervene in every specific case connected to the credit for the housing sector; its most important feature is that it is able to connect data on environmental external costs to financial risks. In this sense, it is, for now, a unique contribution to the debate.

\section{Conclusions}

The green transition requires huge amount of investment. SMEs have particular difficultly finding funding to this end [77], which is why a discount on green financing would truly help. A famous saying states that slow and steady wins the race. However, against climate change, we need to speed up responses to win. Governments and financial operators must focus on policies and tools able to quickly change the economic landscape in order to prevent, in the future, extreme and restrictive policy choices such as a ban on energy inefficient house sales. Therefore, it is paramount that the discussion concentrates on rapidly deployable and incentive-based sustainable finance measures. We gave a detailed example of one of these instruments that can be implemented in the field of banking regulation to help banks and households to go green. The effectiveness of the proposal lies in the fact that, in terms of data and business model of the banks (also as far as their knowledge of prudential rules are concerned), it can be implemented almost immediately, thus pushing a change of financial operators' behavior. In the specific European context, our proposal is also able to embed the ongoing regulatory efforts to involve financial operators in the transition towards an environmentally sustainable economy (EU Taxonomy), and it is in line with the goals posed by the EC for the financial sector. A limitation of our work is that it is based on the EU Taxonomy that is also consistent with the area statistical classification [78]. An international enforcement would require a mapping of the EU Taxonomy into that of the other areas, starting from China.

Moreover, more precise data on single credit lines will allow a more granular calibration of the different. The point is to pass from the general discussions on a green regulatory environment to change the rules of the game. The main policy implication of our work is that there is a quick and effective way to incentivize banks to fund the green transition.

Author Contributions: Section 1: L.E., G.M. (Giuseppe Mastromatteo) and A.M.; Section 2: L.E. and G.M. (Giulio Mela); Section 3: L.E. and A.M.; Section 4: A.M. (methodology, CENED EPC data base elaboration, external cost estimation), P.C.B. (LCA emissions of natural gas consumptions), M.L.C., P.G. and B.M. (LCA emissions of the electricity mix), G.M. (Giuseppe Mastromatteo) (benefit transfer); Section 5: L.E., G.M. (Giulio Mela) and A.M.; Section 6: L.E. All authors have read and agreed to the published version of the manuscript.

Funding: This research received no external funding.

Institutional Review Board Statement: Not applicable.

Informed Consent Statement: Not applicable.

Data Availability Statement: Data on Cened database available at: https://www.cened.it/daticened (accessed on 1 December 2021).

Acknowledgments: The contribute of RSE authors to this work and the APC have been financed by the Research Fund for the Italian Electrical System under the Contract Agreement between RSE S.p.A. and the Ministry of Economic Development-General Directorate for the Electricity Market, Renewable Energy and Energy Efficiency, Nuclear Energy in compliance with the Decree of 16 April 2018. We thank Chiara Belli that, in the research connected to her thesis, has elaborated some of the CENED data we examine (Figure 2).

Conflicts of Interest: The authors declare no conflict of interest. 


\section{Appendix A. Detailed Tables for Emissions and External Costs}

Table A1. Detail of Table 9: Air emissions related to the energy consumption of the study sampleEPC released in January-May 2021-kg-a/100 m².

\begin{tabular}{|c|c|c|c|c|c|c|}
\hline & \multicolumn{6}{|c|}{ Natural Gas-Total Emissions from Well to Household Heat } \\
\hline & $\mathrm{CO}_{2}$ eq & $\mathrm{NO}_{\mathrm{x}}$ & $\mathrm{SO}_{2}$ & NMVOC & $\mathbf{P M}_{2.5}$ & $\mathrm{NH}_{3}$ \\
\hline A4 & 49.3 & 0.04 & 0.04 & 0.03 & 0.01 & 0.0001 \\
\hline $\mathrm{A} 3$ & 233.2 & 0.19 & 0.18 & 0.12 & 0.03 & 0.0004 \\
\hline A2 & 647.3 & 0.53 & 0.49 & 0.34 & 0.09 & 0.001 \\
\hline A1 & 1135.3 & 0.93 & 0.87 & 0.61 & 0.15 & 0.002 \\
\hline B & 1951.1 & 1.59 & 1.49 & 1.04 & 0.26 & 0.003 \\
\hline$C$ & 2514.8 & 2.05 & 1.92 & 1.34 & 0.34 & 0.004 \\
\hline $\mathrm{D}$ & 3337.2 & 2.72 & 2.55 & 1.78 & 0.45 & 0.005 \\
\hline $\mathrm{E}$ & 4400.2 & 3.59 & 3.36 & 2.35 & 0.59 & 0.007 \\
\hline $\mathrm{F}$ & 5845.6 & 4.76 & 4.46 & 3.12 & 0.78 & 0.009 \\
\hline G & 9276.9 & 7.56 & 7.08 & 4.94 & 1.24 & 0.014 \\
\hline All classes & 5465.6 & 4.45 & 4.17 & 2.91 & 0.73 & 0.008 \\
\hline \multirow[t]{3}{*}{ nZEB } & 130.4 & 0.11 & 0.10 & 0.07 & 0.02 & 0.000 \\
\hline & \multicolumn{6}{|c|}{ Electricity-total LCA emissions (Italian mix of sources for gross domestic electricity consumptions) } \\
\hline & $\mathrm{CO}_{2} \mathrm{eq}$ & $\mathrm{NO}_{\mathbf{x}}$ & $\mathrm{SO}_{2}$ & NMVOC & $\mathbf{P M}_{2.5}$ & $\mathrm{NH}_{3}$ \\
\hline A4 & 586.2 & 0.45 & 0.74 & 0.21 & 0.10 & 0.5492 \\
\hline A3 & 926.5 & 0.71 & 1.16 & 0.34 & 0.16 & 0.8680 \\
\hline A2 & 1028.3 & 0.79 & 1.29 & 0.38 & 0.18 & 0.963 \\
\hline A1 & 901.1 & 0.69 & 1.13 & 0.33 & 0.16 & 0.844 \\
\hline $\mathrm{B}$ & 507.3 & 0.39 & 0.64 & 0.19 & 0.09 & 0.475 \\
\hline $\mathrm{C}$ & 447.6 & 0.34 & 0.56 & 0.16 & 0.08 & 0.419 \\
\hline $\mathrm{D}$ & 417.5 & 0.32 & 0.52 & 0.15 & 0.07 & 0.391 \\
\hline $\mathrm{E}$ & 328.3 & 0.25 & 0.41 & 0.12 & 0.06 & 0.308 \\
\hline $\mathrm{F}$ & 275.6 & 0.21 & 0.35 & 0.10 & 0.05 & 0.258 \\
\hline G & 276.5 & 0.21 & 0.35 & 0.10 & 0.05 & 0.259 \\
\hline All classes & 377.7 & 0.29 & 0.47 & 0.14 & 0.07 & 0.354 \\
\hline \multirow[t]{3}{*}{ nZEB } & 755.4 & 0.58 & 0.95 & 0.28 & 0.13 & 0.708 \\
\hline & \multicolumn{6}{|c|}{ Natural gas and electricity consumptions-Emissions of all processes } \\
\hline & $\mathrm{CO}_{2}$ eq & $\mathrm{NO}_{x}$ & $\mathrm{SO}_{2}$ & NMVOC & $\mathbf{P M}_{2.5}$ & $\mathrm{NH}_{3}$ \\
\hline A4 & 635.4 & 0.5 & 0.8 & 0.2 & 0.1 & 0.5 \\
\hline A3 & 1159.7 & 0.9 & 1.3 & 0.5 & 0.2 & 0.9 \\
\hline A2 & 1675.6 & 1.3 & 1.8 & 0.7 & 0.3 & 1.0 \\
\hline A1 & 2036.3 & 1.6 & 2.0 & 0.9 & 0.3 & 0.8 \\
\hline $\mathrm{B}$ & 2458.4 & 2.0 & 2.1 & 1.2 & 0.3 & 0.5 \\
\hline $\mathrm{C}$ & 2962.4 & 2.4 & 2.5 & 1.5 & 0.4 & 0.4 \\
\hline $\mathrm{D}$ & 3754.7 & 3.0 & 3.1 & 1.9 & 0.5 & 0.4 \\
\hline $\mathrm{E}$ & 4728.5 & 3.8 & 3.8 & 2.5 & 0.6 & 0.3 \\
\hline $\mathrm{F}$ & 6121.2 & 5.0 & 4.8 & 3.2 & 0.8 & 0.3 \\
\hline G & 9553.3 & 7.8 & 7.4 & 5.0 & 1.3 & 0.3 \\
\hline All classes & 5843.2 & 4.7 & 4.6 & 3.1 & 0.8 & 0.4 \\
\hline nZEB & 885.8 & 0.7 & 1.0 & 0.3 & 0.1 & 0.7 \\
\hline
\end{tabular}


Table A2. External costs of emissions per unit of mass, Italy (euro $19 / \mathrm{t}$ ), Source: authors' elaboration of Table 24 and Table 49 of the EC Handbook on external costs of transport [59].

\begin{tabular}{|c|c|c|c|c|c|c|}
\hline & $\mathrm{CO}_{2}$ eq & $\mathrm{NO}_{\mathrm{x}}$ & $\mathrm{SO}_{2}$ & NMVOC & $\mathrm{PM}_{2.5}$ & $\mathrm{NH}_{3}$ \\
\hline & Climate Change & & & ollution & & \\
\hline Any stack height & 107.9 & & & 1136 & & 22,299 \\
\hline stack height $<100 \mathrm{~m}$ or unknown height) & & 14,556 & 13,111 & & 45,022 & \\
\hline stack height $\geq 100 \mathrm{~m}$ ) & & 11,759 & 11,627 & & 21,783 & \\
\hline
\end{tabular}

Table A3. Detail of Table 10: External costs of life-cycle air emissions related to the annual energy consumptions of buildings, Lombardy EPC January-May 2021, by energy efficiency class and nZEB, values in euro $/ 100 \mathrm{~m}^{2}$.

\begin{tabular}{|c|c|c|c|c|c|c|c|c|c|}
\hline & \multicolumn{6}{|c|}{ Natural Gas, WTH (from Well to Heat) } & Combustion & $\begin{array}{l}\text { Production, Transport } \\
\text { and Distribution }\end{array}$ & $\begin{array}{l}\text { Total External } \\
\text { Costs }\end{array}$ \\
\hline & $\mathrm{CO}_{2}$ eq & $\mathrm{NO}_{x}$ & $\mathrm{SO}_{2}$ & NMVOC & $\mathrm{PM}_{2.5}$ & $\mathrm{NH}_{3}$ & \multicolumn{3}{|c|}{ All Emissions (Greenhouse Gases and Macro-Pollutants) } \\
\hline A4 & 5.3 & 0.6 & 0.5 & 0.0 & 0.3 & 0.0 & 4.4 & 2.4 & 6.7 \\
\hline A3 & 25.1 & 2.8 & 2.3 & 0.1 & 1.4 & 0.0 & 20.6 & 11.2 & 31.8 \\
\hline A2 & 69.8 & 7.7 & 6.5 & 0.4 & 3.9 & 0.0 & 57.2 & 31.1 & 88.3 \\
\hline A1 & 122.5 & 13.5 & 11.4 & 0.7 & 6.8 & 0.0 & 100.4 & 54.5 & 154.8 \\
\hline B & 210.4 & 23.1 & 19.5 & 1.2 & 11.7 & 0.1 & 172.5 & 93.6 & 266.1 \\
\hline $\mathrm{C}$ & 271.3 & 29.8 & 25.2 & 1.5 & 15.1 & 0.1 & 222.4 & 120.6 & 343.0 \\
\hline $\mathrm{D}$ & 360.0 & 39.6 & 33.4 & 2.0 & 20.1 & 0.1 & 295.1 & 160.1 & 455.2 \\
\hline E & 474.6 & 52.2 & 44.0 & 2.7 & 26.5 & 0.1 & 389.1 & 211.1 & 600.1 \\
\hline $\mathrm{F}$ & 630.5 & 69.4 & 58.5 & 3.5 & 35.2 & 0.2 & 516.9 & 280.4 & 797.3 \\
\hline G & 1000.6 & 110.1 & 92.8 & 5.6 & 55.8 & 0.3 & 820.2 & 445.0 & 1265.3 \\
\hline All classes & 589.5 & 64.8 & 54.7 & 3.3 & 32.9 & 0.2 & 483.3 & 262.2 & 745.4 \\
\hline \multirow[t]{3}{*}{ nZEB } & 14.1 & 1.5 & 1.3 & 0.1 & 0.8 & 0.0 & 11.5 & 6.3 & 17.8 \\
\hline & \multicolumn{6}{|c|}{$\begin{array}{c}\text { Electricity (mix of gross consumptions)—All generation and production } \\
\text { processes }\end{array}$} & Generation & Production processes & Total external costs \\
\hline & $\mathrm{CO}_{2}$ eq & $\mathrm{NO}_{x}$ & $\mathrm{SO}_{2}$ & NMVOC & $\mathrm{PM}_{2.5}$ & $\mathrm{NH}_{3}$ & \multicolumn{3}{|c|}{ All emissions (greenhouse gases and macro-pollutants) } \\
\hline A4 & 63.2 & 6.1 & 9.6 & 0.2 & 4.5 & 12.2 & 40.7 & 55.3 & 95.9 \\
\hline A3 & 99.9 & 9.7 & 15.1 & 0.4 & 7.1 & 19.4 & 64.3 & 87.3 & 151.6 \\
\hline A2 & 110.9 & 10.8 & 16.8 & 0.4 & 7.9 & 21.5 & 71.3 & 96.9 & 168.3 \\
\hline A1 & 97.2 & 9.4 & 14.7 & 0.4 & 6.9 & 18.8 & 62.5 & 84.9 & 147.5 \\
\hline B & 54.7 & 5.3 & 8.3 & 0.2 & 3.9 & 10.6 & 35.2 & 47.8 & 83.0 \\
\hline $\mathrm{C}$ & 48.3 & 4.7 & 7.3 & 0.2 & 3.4 & 9.4 & 31.1 & 42.2 & 73.3 \\
\hline $\mathrm{D}$ & 45.0 & 4.4 & 6.8 & 0.2 & 3.2 & 8.7 & 29.0 & 39.4 & 68.3 \\
\hline$E$ & 35.4 & 3.4 & 5.4 & 0.1 & 2.5 & 6.9 & 22.8 & 31.0 & 53.7 \\
\hline $\mathrm{F}$ & 29.7 & 2.9 & 4.5 & 0.1 & 2.1 & 5.8 & 19.1 & 26.0 & 45.1 \\
\hline G & 29.8 & 2.9 & 4.5 & 0.1 & 2.1 & 5.8 & 19.2 & 26.1 & 45.2 \\
\hline All classes & 40.7 & 4.0 & 6.2 & 0.2 & 2.9 & 7.9 & 26.2 & 35.6 & 61.8 \\
\hline \multirow[t]{3}{*}{ nZEB } & 81.5 & 7.9 & 12.3 & 0.3 & 5.8 & 15.8 & 52.4 & 71.2 & 123.6 \\
\hline & \multicolumn{6}{|c|}{ Natural gas and electricity-All processes } & $\begin{array}{l}\text { Energy } \\
\text { generation } \\
\text { processes }\end{array}$ & Upstream processes & Total external costs \\
\hline & $\mathrm{CO}_{2}$ eq & $\mathrm{NO}_{\mathbf{x}}$ & $\mathrm{SO}_{2}$ & NMVOC & $\mathrm{PM}_{2.5}$ & $\mathrm{NH}_{3}$ & \multicolumn{3}{|c|}{ All emissions (greenhouse gases and macro-pollutants) } \\
\hline A4 & 68.5 & 6.7 & 10.1 & 0.3 & 4.8 & 12.2 & 45.0 & 57.6 & 102.7 \\
\hline A3 & 125.1 & 12.5 & 17.5 & 0.5 & 8.5 & 19.4 & 84.9 & 98.5 & 183.4 \\
\hline A2 & 180.7 & 18.4 & 23.3 & 0.8 & 11.8 & 21.5 & 128.6 & 128.0 & 256.6 \\
\hline A1 & 219.6 & 22.9 & 26.1 & 1.1 & 13.8 & 18.9 & 162.9 & 139.4 & 302.3 \\
\hline B & 265.2 & 28.5 & 27.8 & 1.4 & 15.6 & 10.7 & 207.7 & 141.4 & 349.1 \\
\hline
\end{tabular}


Table A3. Cont.

\begin{tabular}{|c|c|c|c|c|c|c|c|c|c|}
\hline $\mathrm{C}$ & 319.5 & 34.5 & 32.5 & 1.7 & 18.6 & 9.4 & 253.4 & 162.8 & 416.2 \\
\hline $\mathrm{D}$ & 405.0 & 44.0 & 40.2 & 2.2 & 23.3 & 8.8 & 324.0 & 199.5 & 523.5 \\
\hline $\mathrm{E}$ & 510.0 & 55.6 & 49.4 & 2.8 & 29.0 & 7.0 & 411.8 & 242.0 & 653.9 \\
\hline $\mathrm{F}$ & 660.2 & 72.2 & 63.0 & 3.7 & 37.3 & 6.0 & 536.0 & 306.4 & 842.4 \\
\hline G & 1030.5 & 113.0 & 97.3 & 5.7 & 57.9 & 6.1 & 839.4 & 471.1 & 1310.5 \\
\hline All classes & 630.3 & 68.8 & 60.9 & 3.5 & 35.8 & 8.1 & 509.5 & 297.8 & 807.3 \\
\hline nZEB & 95.5 & 9.4 & 13.6 & 0.4 & 6.6 & 15.8 & 63.9 & 77.5 & 141.4 \\
\hline
\end{tabular}

\section{Appendix B. A Stress Test on Green Mortgage in Italy}

To better explain how ERWA could work vis à vis the ordinary RWA, we propose a stress test for the Italian banking system by using available data on residential mortgages and energy efficiency class gains in buildings' renewal. Firstly, the test assesses the baseline "level of convenience" for banks of the current RWA mechanism by calculating the ratio between the capital requirements under Basel 3 rules and the total assets value (residential mortgages outstanding). Lower capital requirements increase in the convenience for bank to push borrowers to develop a building renovation intervention, financing its costs through a loan increase. The test develops three different scenarios related to the implementation of the proposed ERWA tool in financing house purchasing, related to different percentages of house renewals:

- A first scenario where banks, faced with very different capital requirements between inefficient home purchases and renovations, fully succeed to convince borrowers to include in the mortgage a building renovation project $(100 \%$ of mortgages for house purchase with renovations).

- A second scenario where banks convince clients representing only half of the assets ( $50 \%$ of mortgages with renovations).

- A third scenario, which finds out the minimum percentage of renovations that is needed to maintain the same level of convenience of the baseline scenario (the starting ratio between the capital requirements and total assets).

To implement the test, we firstly calculated the matrix representing the shares of the energy class changes attained through current restructuring interventions in Italy (see Table A4). The more recent available data for Italy, related to year 2019 (33,623 EPCs), are offered by an ENEA report [44] that contains data on EPC release motivation classified by energy efficiency class for the period 2016-2019. As can be seen from the high values in the diagonal (no energy class improvement), using historical data is a precautionary assumption in the stress test. Because the proposed ERWA mechanism has been designed to prevent fake renovation (see Section 5.4), future restructuring interventions are expected to provide much deeper energy savings, allowing for lower capital reserves.

Table A5 shows the calculation of the RWA in the year 2019, related to the amount of new residential mortgages in Italy ( 42.19 billion $€$ in 2019) and their breakdown according to the LTV ratio [79]. In the last column, we calculate the RWA by using the Basel 3 weighting coefficients for LTV classes. In the last row, the weighted average of, respectively, the RW coefficients $(0.2711)$ and amounts $(11.44 €$ billion) are calculated. The ratio between the capital requirements under Basel 3 rules (RWA) and the total assets value (new mortgages) is 0.271 ; this provides the baseline "level of convenience" for the banks vis à vis the current RWA mechanism. 
Table A4. Matrix of the changes in EPC after the restructuring interventions in 2019, percentages of the total (estimate), Italy. Source: [69].

\begin{tabular}{|c|c|c|c|c|c|c|c|c|c|c|}
\hline & G & F & E & D & C & B & A1 & A2 & A3 & A4 \\
\hline G & $8.64 \%$ & $7.62 \%$ & $7.54 \%$ & $7.31 \%$ & $4.94 \%$ & $3.68 \%$ & $3.75 \%$ & $2.76 \%$ & $1.62 \%$ & $1.61 \%$ \\
\hline $\mathrm{F}$ & & $4.88 \%$ & $4.83 \%$ & $4.68 \%$ & $3.17 \%$ & $2.36 \%$ & $2.40 \%$ & $1.77 \%$ & $1.04 \%$ & $1.03 \%$ \\
\hline$E$ & & & $3.31 \%$ & $3.21 \%$ & $2.17 \%$ & $1.62 \%$ & $1.65 \%$ & $1.21 \%$ & $0.71 \%$ & $0.71 \%$ \\
\hline $\mathrm{D}$ & & & & $1.96 \%$ & $1.32 \%$ & $0.99 \%$ & $1.01 \%$ & $0.74 \%$ & $0.43 \%$ & $0.43 \%$ \\
\hline C & & & & & $0.53 \%$ & $0.39 \%$ & $0.40 \%$ & $0.30 \%$ & $0.17 \%$ & $0.17 \%$ \\
\hline B & & & & & & $0.17 \%$ & $0.17 \%$ & $0.13 \%$ & $0.07 \%$ & $0.07 \%$ \\
\hline A1 & & & & & & & $0.09 \%$ & $0.06 \%$ & $0.04 \%$ & $0.04 \%$ \\
\hline A2 & & & & & & & & $0.04 \%$ & $0.02 \%$ & $0.02 \%$ \\
\hline A3 & & & & & & & & & $0.01 \%$ & $0.01 \%$ \\
\hline $\mathrm{A} 4$ & & & & & & & & & & $0.01 \%$ \\
\hline
\end{tabular}

Table A5. Italian mortgage for 2019; * data in $€$ billion. Source: for Column 1, Bank of Italy and Mutuionline (for a discussion, see [79]).

\begin{tabular}{ccccc}
\hline LTV Class & \% of New Mortgages & New Mortgages * & RW Coefficient & RWA $^{*}$ \\
\hline$\leq 30 \%$ & $6.3 \%$ & 2.66 & 0.20 & 0.53 \\
\hline $30-40 \%$ & $9.0 \%$ & 3.80 & 0.20 & 0.76 \\
\hline $40-50 \%$ & $16.4 \%$ & 6.92 & 0.20 & 1.38 \\
\hline $50-60 \%$ & $13.9 \%$ & 5.87 & 0.25 & 1.47 \\
\hline $60-70 \%$ & $20.0 \%$ & 8.44 & 0.30 & 2.53 \\
\hline $70-80 \%$ & $27.9 \%$ & 11.77 & 0.30 & 3.53 \\
\hline$>80 \%$ & $6.5 \%$ & 2.74 & 0.45 & 1.23 \\
\hline All classes & & 42.19 & 0.2711 & 11.44 \\
\hline
\end{tabular}

To calculate ERWAs in the three scenarios, we recalculate the mortgage value by including an additional $10 \%$ of the house value to finance the possible renewal intervention, thus obtaining a recalculated LTV (as a further precautionary hypothesis, no increase in the value of the property is assumed).

Finally, Table A6 compares the current capital requirement situation (using the RWA Basel 3 approach as baseline) and the capital requirements for the Italian case under the three scenarios in terms of ERWAs (as said in Section 5.4, the formula to calculate the ERWAs with the current Basel 3 risk weights is $\mathrm{RW} * \mathrm{EW} *$ mortgages).

Results show that the "Taxonomy coherent" environmental weights for residential mortgage house purchases that we propose would increase the capital reserve in each scenario by $15 \%$ (100\% renovations), $22 \%$ (50\% renovations) and $16 \%$ ( $87.5 \%$ renovations), respectively. This effect can be partially or totally counterbalanced by the correspondent increase of asset value (and hence of banks' income). In fact, the asset value increases by $19 \%$ in the $100 \%$ renovations scenario, determining a reduction in the capital reserves to assets ratio of $4 \%$. The parity of this ratio is obtained with a renovation rate of $87.5 \%$ of purchases, while an increase is obtained with lower renovation rates. These results show that the proposed ERWA tool would provide a strong and feasible incentive to the banks for funding green mortgages coupled with building renewals. This incentive can eventually push borrowers to achieve higher energy efficiency class jumps as compared to those prudently assumed in the test (historical shares related to 2019 renovations in Italy). 
Table A6. Capital requirements comparison between the 2019 baseline and three alternative ERWA scenarios with different renovations' percentage on house purchases, for new residential mortgages in Italy. Data for mortgages, RWA and ERWA in $€$ billion.

\begin{tabular}{|c|c|c|c|c|}
\hline & $\begin{array}{c}\text { Baseline (Current } \\
\text { Regulatory Framework) }\end{array}$ & ERWA Scenario & ERWA Scenario & $\begin{array}{c}\text { ERWA Scenario Parity of } \\
\text { Ratio between Capital } \\
\text { Reserves and Assets }\end{array}$ \\
\hline & & $\begin{array}{c}\text { Renovations }=100 \% \text { of } \\
\text { Purchase }\end{array}$ & $\begin{array}{c}\text { Renovations }=50 \% \text { of } \\
\text { Purchases }\end{array}$ & $\begin{array}{c}\text { Renovations }=87.5 \% \text { of } \\
\text { Purchases }\end{array}$ \\
\hline Mortgages outstanding & 42.2 & 50.1 & 46.2 & 49.1 \\
\hline RWA & 11.4 & n.a. & n.a. & n.a. \\
\hline ERWA & n.a. & 13.1 & 14.0 & 13.3 \\
\hline $\begin{array}{l}\text { Ratio between capital } \\
\text { reserves (RWA or ERWA) } \\
\text { and assets (mortgages) }\end{array}$ & 0.271 & 0.262 & 0.302 & 0.271 \\
\hline $\begin{array}{l}\text { Variation of capital reserve } \\
\text { in each scenario as } \\
\text { compared to baseline }\end{array}$ & n.a. & $+15 \%$ & $+22 \%$ & $16 \%$ \\
\hline $\begin{array}{l}\text { Variation of asset value in } \\
\text { each scenario as compared } \\
\text { to baseline }\end{array}$ & n.a. & $+19 \%$ & $+9 \%$ & $+16 \%$ \\
\hline $\begin{array}{l}\text { Variation of capital } \\
\text { reserves to assets ratio as } \\
\text { compared to baseline }\end{array}$ & n.a. & $-4 \%$ & $+12 \%$ & $\begin{array}{c}0 \% \\
\text { (by assumption) }\end{array}$ \\
\hline
\end{tabular}

\section{References}

1. European Commission. Communication of the Commission to the European Parliament, the European Council, the Council, the European Economic and Social Committee, and the Committee of Regions. The European Green Deal. COM (2019) 640 Final, 11.12.2019; European Commission: Brussels, Belgium, 2019. Available online: https:/ / eur-lex.europa.eu/legal-content/EN/TXT/?uri=COM\%3A201 9\%3A640\%3AFIN (accessed on 1 December 2021).

2. European Commission. Communication from the Commission to the European Parliament, the European Council, the Council, the European Economic and Social Committee, and the Committee of Regions. Action Plan: Financing Sustainable Growth. COM (2018) 97 Final, 8.2.2018; European Commission: Brussels, Belgium, 2018. Available online: https:/ / eur-lex.europa.eu/legal-content/EN/ TXT/PDF/?uri=CELEX:52018DC0097\&from=EN (accessed on 1 December 2021).

3. European Commission. Guidelines on Reporting Climate-Related Information; European Commission: Brussels, Belgium, 2019. Available online: https:/ / ec.europa.eu/finance/docs/policy/190618-climate-related-information-reporting-guidelines_en.pdf (accessed on 1 December 2021).

4. European Parliament and the Council of the European Union. Regulation (EU) 2019/2088 of the European Parliament and of the Council of 27 November 2019 on Sustainability-Related Disclosures in the Financial Services Sector; European Commission: Brussels, Belgium, 2019. Available online: https:/ / eur-lex.europa.eu/legal-content/EN/TXT/PDF/?uri=CELEX:32019R2088\&from=EN (accessed on 1 December 2021).

5. European Parliament and the Council of the European Union. Regulation (EU) 2020/852 of the European Parliament and of the Council of 18 June 2020 on the Establishment of a Frame-Work to Facilitate Sustainable Investment, and Amending Regulation (EU) 2019/2088; European Commission: Brussels, Belgium, 2020. Available online: https://eur-lex.europa.eu/legal-content/EN/TXT/PDF/ ?uri=CELEX:32020R0852\&from=EN (accessed on 1 December 2021).

6. European Commission. Commission Delegated Regulation (EU) of 4.6.2021 Supplementing Regulation of 2020/852 of the European Parliament and of the Council by Establishing the Technical Screening Criteria for Determining the Conditions under Which an Economic Activity Qualifies as Contributing Substantially to Climate Change Mitigation or Climate Change Adaptation and for Determining Whether That Economic activity Causes No Significant Harm to Any of the Other Environmental Objectives, Brussels, 4 June 2021, C (2021), 2800 Final. Available online: https: / / eur-lex.europa.eu/resource.html?uri=cellar: d84ec73c-c773-11eb-a925-01aa75ed71a1.0021.02/DOC_1\&format=PDF (accessed on 1 December 2021).

7. European Commission. Communication of the Commission to the European Parliament, the European Council, the Council, the European Economic and Social Committee, and the Committee of Regions. Strategy for Financing the Transition to a Sustainable Economy. COM (2021) 390 Final, 6.7.2021; European Commission: Brussels, Belgium, 2021. Available online: https:/ / eur-lex.europa.eu/resource. html?uri=cellar:9f5e7e95-df06-11eb-895a-01aa75ed71a1.0001.02/DOC_1\&format=PDF (accessed on 1 December 2021).

8. European Commission. Consultation Document Review of the Mortgage Credit Directive; European Commission: Brussels, Belgium, 2021. Available online: https:/ / ec.europa.eu/info/sites/default/files/business_economy_euro/banking_and_finance/ documents/2021-mortgage-credit-review-consultation-document_en.pdf (accessed on 1 December 2021). 
9. European Parliament and the Council of the European Union. Regulation (EU) 2019/876 of the European Parliament and of the Council of 20 May 2019 Amending Regulation (EU) No 575/2013 as Regards the Leverage Ratio, the Net Stable Funding Ratio, Requirements for Own Funds and Eligible Liabilities, Counterparty Credit Risk, Market Risk, Exposures to Central Counterparties, Exposures to Collective Investment Undertakings, Large Exposures, Reporting and Disclosure Requirements, and Regulation (EU) No 648/2012; European Commission: Brussels, Belgium, 2019. Available online: https:/ / eur-lex.europa.eu/legal-content/EN/TXT/PDF/?uri=CELEX: 32019R0876\&from=EN (accessed on 1 December 2021).

10. EBA (European Banking Authority). Action Plan on Sustainable Finance; EBA: Paris, France, 2019.

11. EBA. Consultation paper Draft Implementing Standards on prudential disclosures on ESG Risks in Accordance with Article 449a CRR, EBA/CP/2021/06, 1 3. 2021. Available online: https://www.eba.europa.eu/sites/default/documents/files/document_ library/Publications /Consulta-tions/2021/Consultation\%20on\%20draft\%20ITS\%20on\%20Pillar\%20disclosures $\% 20$ on $\% 20$ ESG\%20risk/963621/Consultation\%20paper\%20on\%20draft\%20ITS\%20on\%20Pillar\%203\%20disclosures\%20on\%20ESG\%20 risks.pdf (accessed on 1 December 2021).

12. Tol, R.S.J. Is the Uncertainty about Climate Change too Large for Expected Cost-Benefit Analysis? Clim. Chang. 2003, 56, 265-289. [CrossRef]

13. van Essen, H.; van Wijngaarden, L.; Schroten, A.; Sutter, D.; Bieler, C.; Maffii, S.; Brambilla, M.; Fiorello, D.; Fermi, F.; Parolin, R.; et al. Handbook on the External Costs of Transport-Version 2019 1.1; DG Mobility and Transport, January 2019; European Commission: Brussels, Belgium, 2019.

14. EC (European Commission). Communication from the Commission's Guidelines on Non-Financial Reporting: Supplement on Reporting Climate-Related Information, 176 2019, C (2019) 4490 Final; EC: Brussels, Belgium, 2019.

15. Molocchi, A. Chi Inquina, Paga? Tasse Ambientali e Sussidi Dannosi per L'ambiente. Ipotesi di Riforma Alla Luce dei Costi Esterni Delle Attività Economiche in Italia; Documento di Valutazione n. 6, Dicembre 2017; Ufficio di Valutazione d'Impatto del Senato: Rome, Italy, 2017.

16. Kriegler, E.; Bertram, C.; Kuramochi, T.; Jakob, M.; Pehl, M.; Stevanović, M.; Höhne, N.; Luderer, G.; Minx, J.; Fekete, H.; et al. Short term policies to keep the door open for Paris climate goals. Environ. Res. Lett. 2018, 13, 074022. [CrossRef]

17. Ganda, F.; Milondzo, K.S. The Impact of Carbon Emissions on Corporate Financial Performance: Evidence from the South African Firms. Sustainability 2018, 10, 2398. [CrossRef]

18. Cahen-Fourot, L.; Campiglio, E.; Godin, A.; Kemp-Benedict, E.; Trsek, S. Capital Stranding Cascades: The Impact of Decarbonisation on Productive Asset Utilization; Ecological Economic Papers 18; WU Vienna University of Economics and Business: Wien, Austria, 2019.

19. Battiston, S.; Dafermos, Y.; Monasterolo, I. Climate risks and financial stability. J. Financ. Stab. 2021, 54, 100867. [CrossRef]

20. Campiglio, E.; van der Ploeg, F. Macro-Financial Transition Risks in the Fight Against Global Warming. RFF-CMCC Work. 2021, 2021, 15-21. Available online: https:/ / www.rff.org/publications/working-papers/macro-financial-transition-risks-in-the-fightagainst-global-warming/ (accessed on 1 December 2021).

21. Jackson, A. A Stock-Flow Consistent Framework for the Analysis of Stranded Assets and the Transition to a Low Carbon Economy; University of Surrey: Guildford, UK, 2018.

22. Dafermos, Y.; Nikolaidi, M. Fiscal policy and ecological sustainability: A post-Keynesian perspective. Post Keynes. Econ. Soc. Work. 2019, 2019, 1912. Available online: http://www.postkeynesian.net/downloads/events/Dafermos_and_Nikolaidi_2019 _MeXedhh.pdf (accessed on 1 December 2021).

23. Roncoroni, A.; Battiston, S.; Escobar-Farfán, L.O.; Martinez-Jaramillo, S. Climate risk and financial stability in the network of banks and in-vestment funds. J. Financ. Stab. 2021, 54, 100870. [CrossRef]

24. Roncoroni, A.; Battiston, S.; D’Errico, M.; Hałaj, G.; Kok, C. Interconnected Banks and Systemically Important Exposures. J. Financ. Stab. 2021, 54, 100870. [CrossRef]

25. Lamperti, F.; Bosetti, V.; Roventini, A.; Tavoni, M.; Treibich, T. Three green financial policies to address climate risks. J. Financ. Stab. 2021, 54, 100875. [CrossRef]

26. Carattini, S.; Heutel, G.; Melkadze, G. Climate Policy, Financial Frictions, and Transition Risk; NBER Working Paper No. 28525; National Bureau of Economic Research: Cambridge, MA, USA, 2021.

27. EBA. Quantitative Impact Study/Basel III Monitoring; EBA: Paris, France, 2021.

28. BCBS (Basel Committee on Banking Supervision). Assessing the Impact of Basel III: Evidence from Macroeconomic Models: Literature Review and Simulations; BIS: Basel, Switzerland, 2021.

29. Esposito, L.; Mastromatteo, G.; Molocchi, A. Environment risk weighted assets: Allowing banking supervision and green economy to meet for good. J. Sustain. Financ.-Vestment 2019, 9, 68-86. [CrossRef]

30. Esposito, L.; Mastromatteo, G.; Molocchi, A. Extending 'environment-risk weighted as-sets': EU taxonomy and banking supervision. J. Sustain. Financ. Invest. 2021, 11, 214-232. [CrossRef]

31. EU Technical Expert Group. Taxonomy Technical Report. 2019. Available online: https://ec.europa.eu/info/sites/info/files/ business_economy_euro/banking_and_finance/documents/190618-sustainable-finance-teg-report-taxonomy_en.pdf (accessed on 1 December 2021).

32. JRC-EBA. Joint JRC-EBA Workshop on Banking Regulation and Sustain-Ability; Alessi, L., Ed.; European Union: Brussels, Belgium, 2020.

33. Berenguer, M.; Cardona, M.; Evain, J. Integrating Climate-Related Risks into Banks' Capital Requirements; I4CE: Paris, France, 2020. 
34. Molocchi, A. From production to consumption: An inter-sectoral analysis of air emissions external costs in Italy. Econ. Policy Energy Environ. 2020, 2, 155-180. [CrossRef]

35. Dafermos, Y.; Nikolaidi, M. How can green differentiated capital requirements affect climate risks? A dynamic macrofinancial analysis. J. Financ. Stab. 2021, 54, 100871. [CrossRef]

36. EU (European Union). Regulation EU 2020/852 on the Establishment of a Framework to Facilitate Sustainable Investment, and Amending Regulation (EU) 2019/2088; EU: Brussels, Belgium, 2020.

37. Khasreen, M.; Banfill, P.F.G.; Menzies, G.F. Life-Cycle Assessment and the Environmental Impact of Buildings: A Review. Sustainability 2019, 3, 674. [CrossRef]

38. Mesa, J.A.; Fúquene-Retamoso, C.; Maury-Ramírez, A. Life Cycle Assessment on Construction and Demolition Waste: A Systematic Literature Review. Sustainability 2021, 13, 7676. [CrossRef]

39. Artola, I.; Rademaekers, K.; Williams, R.; Yearwood, J. Boosting Building Renovation: What Potential and Value for Europe? Report for the European Parliament, PE 587.326; European Parliament: Brussels, Belgium, 2016.

40. Eurostat. Disaggregated Final Energy Consumption in Households-Quantities [NRG_D_HHQ_custom_1199272]. 2021. Available online: https:/ / ec.europa.eu/eurostat/databrowser/view/NRG_D_HHQ_custom_1199272/default/table?lang=en (accessed on 1 December 2021).

41. EMF (European Mortgage Federation). Hypostat 2020; A Review of Europe's Mortgage and Housing Markets; EMF: Brussels, Belgium, 2020.

42. EC. Communication from the Commission, A Renovation Wave for Europe-Greening our Buildings, Creating Jobs, Improving Lives; EC: Brussels, Belgium, 2020.

43. Zangheri, P.; Armani, R.; Kakoulaki, G.; Bavetta, M.; Martirano, G.; Pignatelli, F.; Baranzelli, C. Building Energy Renovation for Decarbonisation and Covid-19 Recovery; A Snapshot at Regional Level, JRC-European Commission, EUR 30433 EN; European Union: Luxembourg, 2020.

44. ENEA (Ente nazionale Energie Alternative). Rapporto Annuale Sulla Certificazione Energetica Degli Edifici; ENEA: Rome, Italy, 2021.

45. BCBS. High-Level Summary of Basel III Reforms; BIS: Basel, Switzerland, 2017.

46. EeMAP. A Review of the State of Play on 'Green' Finance. 2017. Available online: https:// eemap.energyefficientmortgages.eu/ wp-content/uploads/2018/04/EeMAP-Technical-Report-on-Green-Finance.pdf (accessed on 1 December 2021).

47. EeMAP. Final Report on the Correlation between Energy Efficiency and Probability of Default. 2019. Available online: https: / / eemap.energyefficientmortgages.eu/wp-content/uploads/EeMAP_D5.4_EMF-ECBC.pdf (accessed on 1 December 2021).

48. Billio, M.; Costola, M.; Pelizzon, L.; Riedel, M. Buildings' Energy Efficiency and the Probability of Mortgage Default: The Dutch Case. J. Real Estate Financ. Econ. 2021. Available online: https://link.springer.com/article/10.1007/s11146-021-09838-0?gclid= EAIaIQobChMIr6OD46PY9QIVAJRmAh0suA4MEAAYAiAAEgKIN_D_BwE\#citeas (accessed on 1 December 2021).

49. Billio, M.; Costola, M.; Pelizzon, L.; Riedel, M. Final Report on Correlation Analysis between Energy Efficiency and Risk, WP5/D5/7, EdDaPP. 2020. Available online: https://energyefficientmortgages.eu/wp-content/uploads/2021/07/ItalianCorrelation-Analysis.pdf (accessed on 1 December 2021).

50. Zancanella, P.; Bertoldi, P.; Boza-Kiss, B. Energy Efficiency, the Value of Buildings and the Payment Default Risk; JRC Science for Policy Report; European Commission: Ispra, Italy, 2018.

51. Guin, B.; Korhonen, P. Does Energy Efficiency Predict Mortgage performance? Bank of England, Staff Working Paper no. 852; Bank of England: London, UK, 2020.

52. EeMAP. Consumer Research Insight. 2018. Available online: https://eemap.energyefficientmortgages.eu/wp-content/uploads/ 2018/04/EeMAP_D2.7_E.ON_Final.pdf (accessed on 1 December 2021).

53. Mangialardo, A.; Micelli, E.; Saccani, F. Does Sustainability Affect Real Estate Market Values? Empirical Evidence from the Office Buildings Market in Milan (Italy). Sustainability 2018, 11, 12. [CrossRef]

54. Bertalot, L.; Johnson, J.; Garrido, S. Energy Efficient Mortgages Initiative: Firm Steps towards Making EEM a Reality in the Market. In ECBC: European Covered Bond Fact Book 2020; EMF-ECBC: Brussels, Belgium, 2020. Available online: https: //hypo.org/app/uploads/sites/2/2020/10/ECBC-Fact-Book-2020-Online.pdf (accessed on 1 December 2021).

55. Prina, M.G.; Fornaroli, F.C.; Moser, D.; Manzolini, G.; Sparber, W. Optimisation method to obtain marginal abatement cost-curve through EnergyPLAN software. Smart Energy 2021, 1, 100002. [CrossRef]

56. CENED. Database CENED+2-Certificazione ENergetica degli EDifici. Elenco pratiche Attestati di Prestazione Energetica (APE) per la certificazione energetica degli edifici sul suolo della Regione Lombardia. Regione Lombardia Open Data. 2021. Available online: https:/ / www.dati.lombardia.it/Energia/Database-CENED-2-Certificazione-ENergetica-degli-E/bbky-sde5 (accessed on 1 December 2021).

57. Ferrari, S.; Baldinazzo, M. Valutazione Delle Prestazioni Energetiche Negli Edifici nZEB; Report Ricerca di Sistema Elettrico: Milan, Italy, 2017.

58. IPCC. Fifth Assessment Report; United Nations: Geneve, Switzerland, 2013.

59. Kuenen, J.; Trozzi, C. (Eds.) EMEP/EEA Air Pollutant Emission Inventory Guidebook 2019; 1.A.4 Small Combustion; EEA: Copenhagen, Denmark, 2019. Available online: https:/ / www.eea.europa.eu/publications/emep-eea-guidebook-2019/part-bsectoral-guidance-chapters/1-energy/1-a-combustion/1-a-4-small-combustion/view (accessed on 1 December 2021).

60. Wernet, G.; Bauer, C.; Steubing, B.; Reinhard, J.; Moreno-Ruiz, E.; Weidema, B. The Ecoinvent database version 3 (part I): Overview and methodology. Int. J. Life Cycle Assess. 2016, 21, 1218-1230. [CrossRef] 
61. Eurostat. Eurostat, Energy Balances; Eurostat: Luxembourg, 2020. Available online: https://ec.europa.eu/eurostat/web/energy/ data/energy-balances (accessed on 1 December 2021).

62. TERNA. Pubblicazioni Statistiche, Annuario Statistico Dati Generali; TERNA: Rome, Italy, 2018. Available online: https://download. terna.it/terna/1-Sez_DATI\%20GENERALI_8d7304e358d68bd.pdf (accessed on 1 December 2021).

63. GSE (Gestore Servizi Energetici). Energia da Fonti Rinnovabili in Italia, Rapporto Statistico 2019; Direzione Studi e Monitoraggio di Sistema: Rome, Italy, 2021. Available online: https:/ / www.gse.it/documenti_site/Documenti\%20GSE/Rapporti\%20statistici/ Rapporto\%20Statistico\%20GSE\%20-\%20FER\%202019.pdf (accessed on 1 December 2021).

64. Gargiulo, A.; Girardi, P.; Mela, G. Life Cycle Assessment Della Produzione di Energia Elettrica Nazionale Attuale ed al 2030; Rapporto Ricerca di Sistema; RSE 19012876: Milan, Italy, 2019.

65. Eurostat-OECD/IEA. Energy Statistic Manual; Eurostat: Luxembourg, 2004.

66. Gargiulo, A.; Carvalho, M.L.; Girardi, P. Life Cycle Assessment of Italian Electricity Scenarios to 2030. Energies 2020, 13, 3852. [CrossRef]

67. Delft, C.E.; Infras Ricardo, T.R.T. Handbook on the External Costs of Transport; Van Hessen, H., Ed.; European Commission, DG Mobility and Transport, version 1.1; European Commission: Brussels, Belgium, 2019. Available online: https://op.europa.eu/en/ publication-detail/-/publication/9781f65f-8448-11ea-bf12-01aa75ed71a1 (accessed on 1 December 2021).

68. Bickel, P.; Friedrich, R. Externalities of Energy, Methodology Update; European Commission DG Research: Luxembourg, 2005 Available online: http://www.externe.info/externe_d7/sites/default/files/methup05a.pdf (accessed on 1 December 2021).

69. Desaigues, B.; Ami, D.; Hutchison, M.; Rabl, A.; Chilton, S.; Metcalf, H.; Farreras, V. Final Report on the Monetary Valuation of Mortality and Morbidity Risks from Air Pollution. Deliv. D6 2007, 7, $20-22$.

70. CASES (Cost Assessment for Sustainable Energy Systems). Coordination Action by the EC under the Sixth Framework Programme, Priority 6.1.3.2.5, Sustainable Energy Systems; CASES: Brussels, Belgium, 2008.

71. CASES. Deliverable 2.2, External Costs Per Unit Emissions, Excel Tool; CASES: Brussels, Belgium, 2008.

72. Brander, L. Guidance Manual on Value Transfer Methods for Ecosystem Services; United Nations Environment Programme (UNEP): Nairobi, Kenya, 2013.

73. Martini, C.; Tiezzi, S. Is the environment a luxury? An empirical investigation using revealed preferences and household production. Resour. Energy Econ. 2014, 37, 147-167. [CrossRef]

74. Navrud, S. Value Transfer Techniques and Expected Uncertainties; Project Deliver-Able n ${ }^{\circ}$ 2.1-RS 3a-NEEDS Project; SWECO: Stockholm, Sweden, 2009.

75. OECD. Valuing Mortality Risk Reductions in Regulatory Analysis of Environmental, Health and Transport Policies: Policy Implications; OECD: Paris, France, 2011. Available online: www.oecd.org/env/policies/vsl (accessed on 1 December 2021).

76. Thomä, J.; Gibhardt, K. Quantifying the Potential Impact of a Green Supporting Factor or Brown Penalty on European Banks and Lending. J. Financ. Regul. Compliance 2019, 2783, 380-394. [CrossRef]

77. Xiang, D.; Zhang, Y.; Worthington, A.C. Determinants of the Use of Fintech Finance Among Chinese Small and Medium-Sized Enterprises. IEEE Trans. Eng. Manag. 2021, 68, 1590-1604. [CrossRef]

78. Ehlers, T.; Diwen, N.G.; Packer, F. A Taxonomy of Sustainable Finance Taxonomies; BIS: Basel, Switzerland, 2021.

79. Carella, A.; Ciocchetta, F.; Signoretti, F.M.; Michelangeli, V. What Can We Learn about Mortgage Supply from Online Data? QEF of the Bank of Italy No. 583: Rome, Italy, 2020. 